
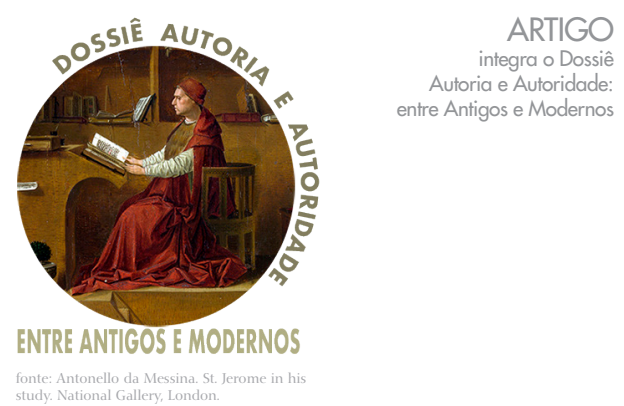

$$
\begin{array}{r}
\text { Contato } \\
\text { Programa de Pós-Graduação em História - UnB } \\
\text { ICC Norte, Módulo 24, Asa Norte } \\
70910-900 \text { - Brasília - Distrito Federal - Brasil } \\
\text { luizdesajunior@gmail.com }
\end{array}
$$

\section{ALEGORIAS DE UMA GUERRA POÉTICA: FIGURAS DA AUTORIDADE NA FRANÇA DO SÉCULO XVII'}

- Luiz César de Sá ${ }^{2}$

Universidade de Brasília

Brasília - Distrito Federal - Brasil

\title{
Resumo
}

Na França do século XVII, consolida-se o entendimento de que as "querelas" são o mecanismo privilegiado de instituição da autoridade letrada. Escritos propondo disputas galantes, que enalteciam a violência verbal em contraposição aos horrores da guerra, disseminam-se até fundamentar um gênero específico. Este artigo se volta para a análise das relações entre autoridade e controvérsia assim fundamentadas a partir do estudo da Nouvelle Allégorique (1658), texto de Antoine Furetière que alegoriza os conflitos letrados de seu tempo com o objetivo princi-

\section{Palavras-chave} pal de arquivar o próprio ato de querelar.

autoridade - controvérsia - alegoria - memória - Antoine Furetière

\footnotetext{
1 Artigo não publicado em plataforma preprint. Todas as fontes e bibliografia utilizadas são referenciadas no artigo. Este texto contou com financiamento da Fundação de Apoio à Pesquisa do Distrito Federal - FAP-DF - Edital Demanda Espontânea nº 03/2018 (processo 0019300002177/2018-21).

2 Doutor em História Social pela Universidade Federal do Rio de Janeiro, Luiz César de Sá é professor adjunto de teoria e filosofia da história e coordenador do Programa de Pós-Graduação em História da Universidade de Brasília. É autor de Escrever para não morrer: retórica da imortalidade no epistolário de Damião de Góis, publicado pela Imprensa da Universidade de Coimbra em 2018.
} 


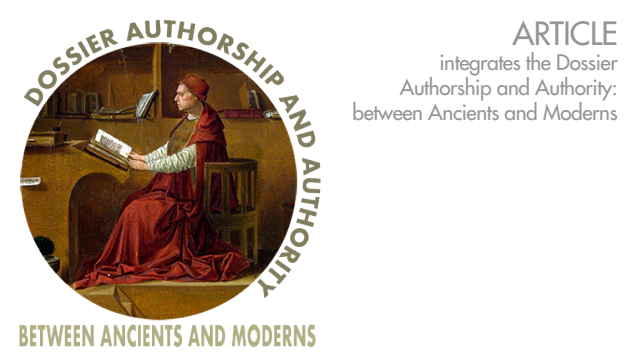

ARTICLE
ALLEGORIES OF A POETIC WAR:

FIGURES OF AUTHORITY

IN $17^{\text {TH }}$ CENTURY

\section{FRANCE}

Contact

Programa de Pós-Graduação em História - UnB ICC Norte, Módulo 24, Asa Norte $70910-900$ - Brasília - Distrito Federal - Brazil luizdesajunior@gmail.com

\section{- Luiz César de Sá}

Universidade de Brasília

Brasília - Distrito Federal - Brazil

\begin{abstract}
In the $17^{\text {th }}$ century France, the understanding that "quarrels" are the privileged mechanism for the institution of authority gains ground. Writings proposing gallant disputes, which praised verbal violence as opposed to the horrors of war, are vastly disseminated, giving birth to a specific genre. This article focuses on the analysis of the relations between authority and controversy formed by this genre based on the study of Antoine Furetière's Nouvelle Allégorique (1658), a book that allegorizes the scholarly hostilities of its time with the main goal of archiving the very act of quarreling.
\end{abstract}

\title{
Keywords
}

authority - controversy - allegory - memory - Antoine Furetière - 


\section{Anamorfose de posições em controvérsia}

Tomados em sua generalidade tipológica, os discursos polêmicos dos tempos de Luís XIII e Luís XIV extraíam consistência de dispositivos que, desaparecido o regime letrado e teológico-político inerente a seu funcionamento, deixaram de ser evidentes: o controle de técnicas antigas da violência verbal, a atualização prudente da memória das guerras de religião, a administração galante das paixões. Quando a intensidade da vida se dobrava à vida das formas a ponto de engastar a matéria empírica dos diferendos na encenação pública de causas sempre repostas, a linguagem assumia um empenho teatral que ainda hoje corre o risco de ser menosprezado por parecer afetado e literário. ${ }^{3}$

Não entre muita crítica contemporânea, em cujos esforços imperou, $a$ contrario, a igualmente incerta tentativa de mobilização documental ${ }^{4}$ de materiais transformados em testemunhos diretos de uma experiência que haveria de colher com confiança positiva ou de estados mentais ou ideológicos estáveis. ${ }^{5}$ Antes, vale a pena a enfocar o caráter anônimo dos mecanismos sociohistóricos de embate ${ }^{6}$ sem neutralizar a especificidade dos casos estudados, entendendo-os como resíduos de ações escriturárias (CANTILLON et al., 2016, p. 9-25) no bojo das lutas de classificação da sociedade francesa.

\footnotetext{
3 Caso, sobretudo, de materiais polêmicos associados a escritores hoje absorvidos pelo cânone literário, a exemplo de Swift em sua Battle of the books e no ainda mais célebre Travels into several remote nations of the world (ou Gulliver's Travels) e de Furetière e a Nouvelle Allégorique de que trata este texto, cujo teor alegórico mais imediato acabou canibalizando grande parte das pretensões de "discurso verdadeiro" e os efeitos sociais a que outrora visou.

${ }^{4}$ Isso sucede com libelos e outros discursos de controvérsia da primeira época moderna, que, tomados apenas em seu caráter literal de "notícia", pouco informam. É imperativo atualizar os procedimentos de sua análise - o que se tem feito nos últimos anos - para, ao questionar o caráter puramente "documental" pressuposto neles, poder usufruir dos benefícios heurísticos de encará-los sob o prisma dos vetores históricos de uma prática agônica - a que aqui buscaremos ler.

${ }^{5}$ Consulte-se a obra de Christian Jouhaud $(2000,2015)$, bastante eficaz na crítica desses pressupostos. De resto, é indispensável marcar que "as querelas não são principalmente conflitos de ideias, mas, antes, oposições de textos, publicações e contra publicações [...]" (TADIÉ \& HOSTIOU, 2019, p. 8). No original, "les querelles sont ne sont pas principalement des conflits d'idées, mais bien des oppositions de textes, des publications et contre-publications [...]". Todas as traduções, salvo menção em contrário, são de nossa responsabilidade.

${ }^{6}$ Mecanismos que abrangem, neste caso, os gêneros discursivos, os critérios de constituição dos públicos e da representação, a formatação teológico-jurídica das relações sociais, o caráter de "artefato" dos resíduos de que se parte para recuperar ações escriturárias, isto é, sua materialidade, as ingerências de livreiros e impressores e outros agentes do livro contra a falsa hegemonia da identidade autoral etc. (PÉCORA, 2001; HANSEN, 2020, CHARTIER, 2015).
} 
A Nouvelle Allégorique ou histoire des derniers troubles arrivez au royaume d'éloquence, levada às prensas por Antoine Furetière e pelo impressor Pierre Lamy em 1658 , oferece um campo de análise propício à evidência de tudo isso, pois pode ser facilmente cooptada por leituras superficiais, dissolvendo-se em deleite indiferente aos negócios do mundo que a cercava, ou sucumbir aos que prefeririam ver nela indícios do "nascimento do escritor", da preparação da Modernidade, da invenção da literatura (TADIÉ \& HOSTIOU, 2019, p. 8-9).

O livro dramatiza disputas entre figuras da elocução a partir do comando e intervenção de autoridades antigas e coevas, que percorrem gêneros discursivos, objetos e instituições de modo a constituir alegoricamente um campo de guerras poéticas. Estas guerras também canalizavam a "energia poética da verdade" (PÉCORA, 2001, p. 150), convocando efeitos realistas de reconhecimento legíveis desde a disposição gráfica do "mapa do conflito" com que a história tem início (figura 1), em tudo semelhante a mapas realistas do período ${ }^{8}$, sem equivaler à transposição de "eventos" voltados para a recapitulação histórica das vidas dos indivíduos implicados. ${ }^{9}$ Por isso, busca-se sustentar a hipótese de que tenha sido constituída como um arquivo do próprio ato de querelar. Ainda que os efeitos das disputas se fizessem sentir nos ecos da alegoria, sua dimensão "contextual" foi deformada, em registro joco-sério, em nome do que era de fato essencial: mostrar quem estava autorizado a participar legitimamente dos embates.

\footnotetext{
7 O privilégio indica, ademais, a extensão dos direitos ao livreiro Guillaume de Luynes (FURETIËRE, 1658, s/p), que podia comercializá-lo, o que logo ocorreu em nova edição, na qual se verificam algumas variantes.

${ }^{8}$ Veja-se, por exemplo, o mapa da bataille des Dunes (figura 2), ocorrida cerca de um mês após a publicação da Nouvelle Allégorique (PONNOU et al, 2013, p. 85).

9 Lembremos, por exemplo, a disseminação de mapas alegóricos no período, a exemplo da Cartedu Tendre, igualmente pertinentes na montagem da Nouvelle Allégorique. (BOMBART \& SCHAPIRA, 2004, p. XII).
} 


\section{Figura 1}

Antoine Furetière. Nouvelle Allégorique [...]. 1658.

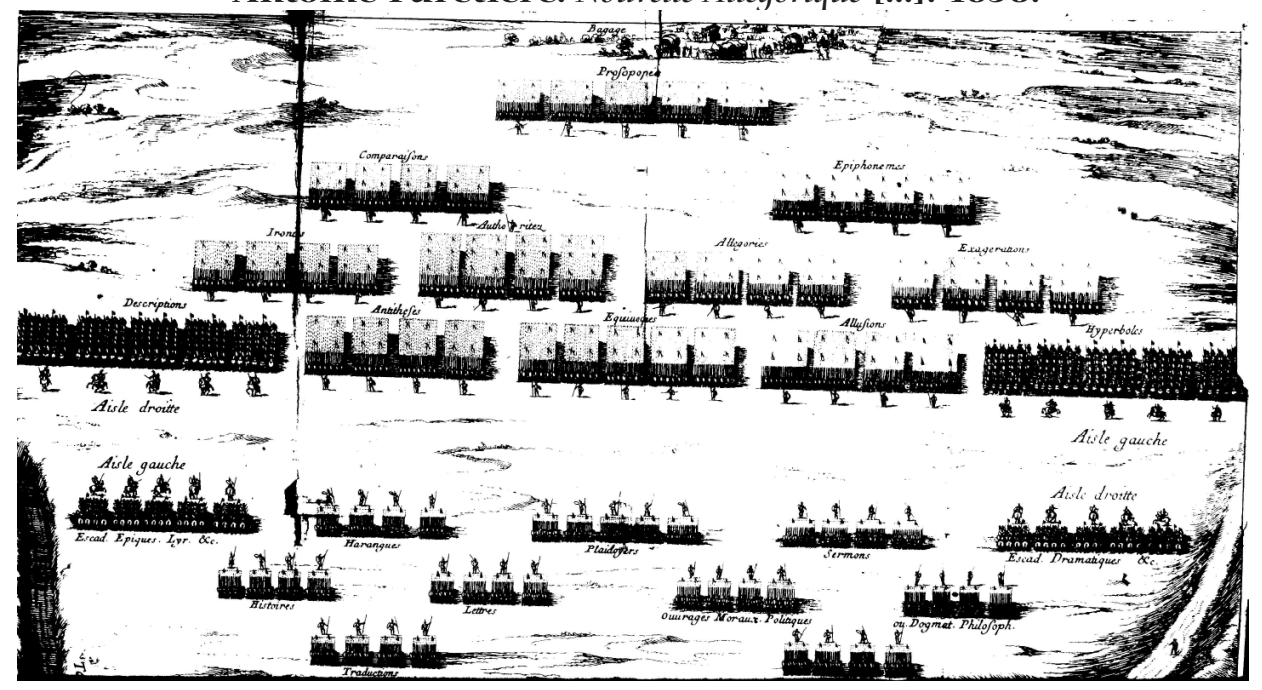

Paris: Bibliothèque Nationale de France. Foto: Wikimedia Commons.

\section{Figura 2}

Sebastian Beaulieu. Bataille des Dunes prèz Dunkerque gagnée par l'armée du roy en 1658.

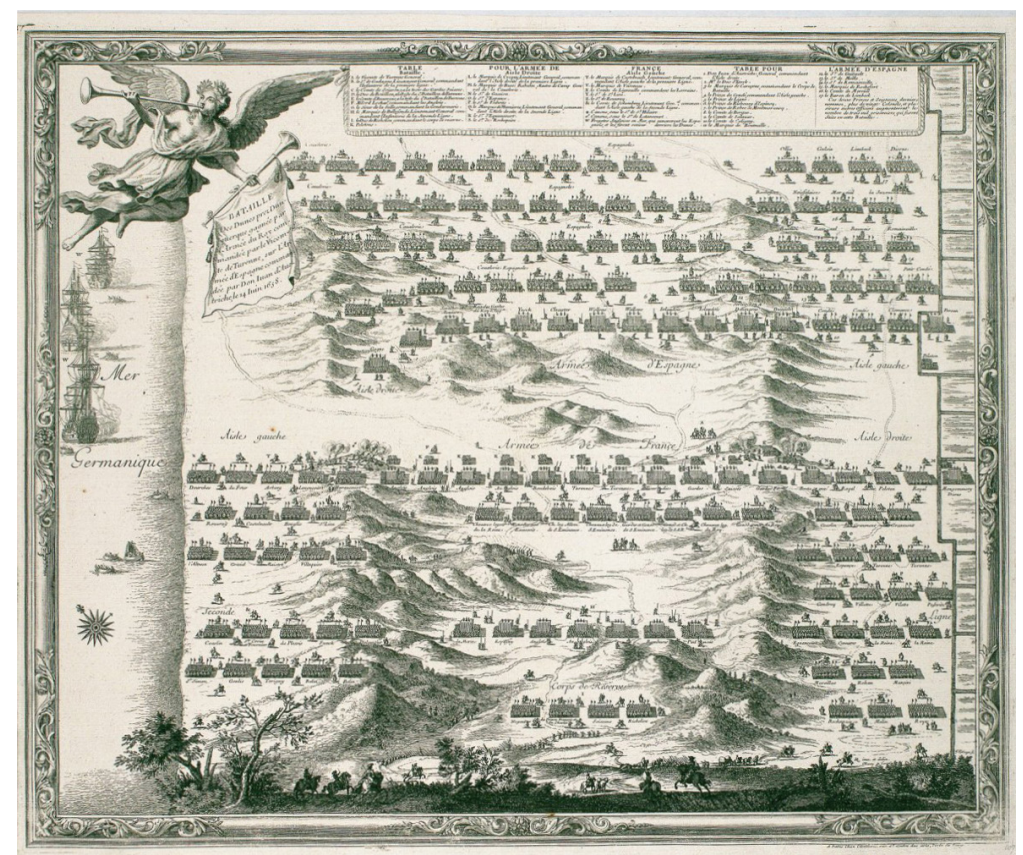

Gravura, 1698. Marburg: Hessisches Staatsarchiv. Foto:Wikimedia Commons. 
Discutir o tema de modo sumário requer ao menos quatro exercícios, traduzidos nas partes do argumento a seguir desenvolvido. Primeiro, explicitar os vínculos entre autoridade e controvérsia subjacentes à longa duração da prática cultural em que foi ordenada. Segundo, diferenciá-la mediante a contextualização das matérias de que trata. Terceiro, apontar funções das alegorias aplicadas segundo os decoros e efeitos da cena que ela acaba dispondo. Quarto, sustentar que a alegoria tinha por fulcro constituir um acervo letrado disponível ao consumo póstero.

Ler a Nouvelle Allégorique pressupõe ciência da simbiose de dois dispositivos letrados decisivos: a auctoritas e a controversia. Definida em estrita relação com a fides, a boa fé própria de discursos virtuosos, a auctoritas servia de critério de apuração da excelência (DE SÁ, 2017, 2019); sob ela, esperava-se que os letrados discernissem os melhores predicados de determinado gênero, modificando-os de modo a evidenciar seu próprio mérito, a ser aferido por um público constituído como representação subordinada que supostamente aplaude o que lê e testemunha. O exercício dessa competição era relacional, de modo que o discurso tido por eficaz causava um deslocamento da hierarquia, usualmente representada como ascensão à "imortalidade".

Quintiliano mobiliza o termo para fundamentar todo uso da linguagem, e supõe que a auctoritas se organiza ao redor da analogia, da antiguidade e do costume (I, VI, 1-2). "Em verdade", lê-se na Instituição oratória:

O costume é o mestre mais certo de se falar, devendo-se usar inteiramente a linguagem como o dinheiro, cuja forma é pública. Tudo isso, porém, exige julgamento acurado e principalmente a analogia que denominaram proportionem em recente tradução do grego para o latim. Sua importância consiste em relacionar o que é duvidoso com algo semelhante, de que não se questione, e em provar o que é incerto pelo que é certo (I, VI, 3-4). ${ }^{10}$

A auctoritas operou segundo formas inscritas em gêneros. Os valores de cada escrito eram avaliados à luz dos que melhor trataram dele, assumindo-se que a persistência de testemunhos antigos certificava seu valor. A "força da antiguidade" (I, V, 72) reside na rede de analogias que cancela as diferenças impostas pelo tempo, propiciando a emulação. Trata-se, portanto, de um dispositivo simbólico de tipos retórico-poéticos que se digladiam em combates letrados cujo prêmio é o prolongamento de suas presenças entre-

\footnotetext{
${ }^{10}$ O termo "uso", empregado na edição brasileira, foi substituído por "costume", mais adequado aos propósitos deste argumento para verter a expressão consuetudo.
} 
tanto cada vez mais ausentes, oferecidas ao consumo e rivalidade futuros em formas fantasmáticas.

Em linguagem judiciária, o termo relaciona-se ao verbo augere, aumentar, assinalando, nos moldes de sua contraparte oratória, valor; a pertinência de uma determinação do senado romano fundamenta-se na auctoritas, o que também se aplica ao pacto estabelecido entre um vendedor e seu cliente e ao direito de comando que um pater tem sobre a família. Em todos os casos, remete à ancestralidade do hábito que filhos têm de obedecer aos genitores, à obrigação do povo de se sujeitar à sapiência do senado e às garantias devidas às partes de uma permuta. A auctoritas amplificava os efeitos desses "contratos", servindo de caução a pactos que, se podiam ser quebrados, trariam punições exemplares em caso de desobediência. É nesse sentido que Theodor Mommsem viria a defini-la muitos séculos mais tarde: "mais do que um conselho e menos do que uma ordem" (D'ALLONES, 2006, p. 25-28). Através dos escombros onde se encontram vestígios de seus usos, auctoritas é, em suma, mecanismo performativo capaz de ativar a autoridade do tempo $^{11}$, suspendendo descrenças sobre atos e ditos passados para suscitar o reconhecimento e a submissão, seu corolário até ao menos o século XVIII. ${ }^{12}$

Não havia auctoritas sem controvérsia. Todavia, esta, além de definir um recurso genérico próprio daquele regime de discursos, também designava um gênero particular, a controversia. Para se tornarem versados nela, jovens romanos dedicavam-se às técnicas da declamatio. Após analisar um preâm-

\footnotetext{
${ }^{11}$ Esse aspecto foi sugerido por François Hartog: “Comptait, pour les Romains, le caractère sacré de la fondation: auctores imperii Romani conditoresque, selon la formule de Pline, 'les initiateurs', 'fondateurs' et 'garants' tout à la fois de la puissance romaine. A suivre les suggestions de l'étymologie, l'autorité est ce qui vient 'augmenter' la fondation, auctoritas renvoyant au verbe augere (augmenter, faire croître) elle est ce qui fait pousser" (HARTOG, 2009, p. 51). "Importava, para os romanos, o caráter sagrado da fundação: auctores imperii Romani conditoresque, segundo a fórmula de Plínio, ao mesmo tempo 'os iniciadores', 'fundadores' e 'fiadores' do poder romano. A seguir as sugestões da etimologia, a autoridade é o que vem 'aumentar' a fundação; remetendo ao verbo augere (aumentar, fazer crescer), ela é aquilo que move".

${ }^{12}$ Registra-se perspectiva semelhante entre letrados setecentistas, a exemplo de Claude-Pierre Goujet, que, ao associar sua incapacidade de mudar os rumos da "república das letras" à ausência de autoridade, reforçava seu caráter de dispositivo garantidor da submissão: "Mais comme mon autorité n'est pas assez grande dans la république de lettres, pour obliger mes lecteurs à se soumettre à mes décisions, je suis presque partout la méthode de M. Baillet: je rapporte plus les jugements des Savants que les miens". GOUJET, 1741, p. vi) "Mas, como minha autoridade não é tão grande na república das letras para obrigar meus leitores a se submeterem às minhas decisões, sigo quase sempre o método de M. Baillet: informo mais os juízos dos Eruditos que os meus próprios".
} 
bulo fornecido pelo rétor, os estudantes produziam ponderações engenhosas acerca dos dois lados de um debate, sendo exigido que sustentassem publicamente argumentos apropriados a cada um deles. Como tratassem de problemas alambicados, paradoxais ou de todo fictícios, os discursos calcados no gênero controversia não se destinavam exclusivamente ao convencimento, mas à demonstração das virtudes do orador (SANS, 2015, p. 2-3). Os discípulos, ao praticarem a controvérsia, deviam conceber prontamente exercícios complexos e artificiosos, capazes de mobilizar as três formas de prova (ethos, logos, pathos) e os cinco procedimentos discursivos (inventio, dispositio, elocutio, memoria, actio) em modalidades concernentes a cada audiência.

Em Quintiliano se observa que o uso das controversiae como forensium actionum meditatio (IV, 2, 29) remontava aos gregos, com Demétrio de Falero, embora tenham alcançado mais relevância no tempo de Cícero, quando se supunha que o estudo de casos fictícios sobrepujaria a análise das empirias do tribunal, pois aqueles acarretavam proposições gerais que iluminariam todos as situações com que o orador poderia se defrontar em um julgamento (Orator, XIV, 44).

Muito presentes na Nouvelle Allégorique, os dispositivos polêmicos de constituição da auctoritas constituem o núcleo argumentativo do texto: esboçar, para além da desordem do conflito, a ordem a vincular monarquia e letrados a partir de posições em controvérsia, fixadas em um formato cênico evidente com o auxílio das técnicas seiscentistas da anamorfose que os letrados envolvidos nas tramas da polêmica suscitada pela Nouvelle Allégorique sabiam distinguir.

Na última proposição de La perspective curieuse, avec l'optique et la catoptrique, de 1638, o franciscano Jean François Niceron desvaloriza técnicas que exponham o artifício subjacente à construção das imagens imediatamente diante dos olhos do público, defendendo ser preciso ocultá-lo de modo a que a pintura fosse resolvida de modo diferencial, mas ordenado, conforme a distância e os aparatos com que era vista. A representação dotada de "graça" seria sempre aquela que se impusesse sobre a "desordem" e a "confusão" das partes que a compõem. Exemplifica-o comentando uma tela do convento de sua ordem (figura 3), na qual aparecem quinze retratos de "otomanos vestidos ao modo Turco" tal como encontrados no Icones Sultanorum. À primeira vista indecorosa, ela revelava seu verdadeiro conteúdo com o auxílio da manipulação das posições de observação: mirar a imagem com a luneta do juízo, para além da literal, revelava o retrato de Luís XIII, resultado da combinação de partes das figuras otomanas. $\mathrm{O}$ exemplo entrelaça maestria técnica, agudeza da percepção e ciência dos princípios metafísicos que organizam o mundo em que a figura foi composta: 
Este desenho é feito com base na Profecia - ao menos tida por tal entre aqueles a quem fora dada - que Maomé outrora legou a seus sucessores, recomendando-lhes jamais ofender a Monarquia Francesa, pois seu império somente viria a ser arruinado pelo poder de algum de seus Reis. Diante disso, desejando mostrar que a honra desta conquista não pertence de modo algum a outro senão Luís, o Justo, fazemos com que a maioria dos Imperadores neste quadro lhe prestem homenagem, de forma que cada um deles contribua com uma parte de si para formar sua imagem, como se eles próprios se despojassem para honrar seu triunfo (NICERON, 1638, p. 115). ${ }^{13}$

A ambivalência entre icástico e fantástico, típica das doutrinas do juízo de seu tempo, é aproveitada por Niceron para propor que artimanhas do gênero são permitidas aos pintores para "exprimir verdades" sob a aparência do falso e da ignomínia por acionarem a "inconveniência conveniente" ou o "despropósito proposital" capazes de engendrar estupor (HANSEN, 2018, p. 3941). Assim, a condenável homenagem aos turcos passa de súbito à revelação do louvor de um império regido por um monarca "Mui Cristão", fundamento "inquebrável da piedade e da religião" (NICERON, 1638, p. 116). A skenographia "belicosa" (COUTON, 1990, p. 115) de Niceron parte do cálculo das distâncias, mesmo procedimento adotado por Furetière para, em meio ao caos ensurdecedor do conflito, em que "partidos" opostos se chocam violentamente, fazer emergir o retrato unívoco de uma paz ornada na superfície polida de suas contradições. A comunicação entre alegoria e pintura, subordinada às tópicas do ut pictura poesis, está, portanto, na base da Nouvelle Allégorique.

\footnotetext{
15 “Ce dessein est fait à propôs de la Prophetie, au moins tenuë telle, par ceux, à qui elle a este donné, que Mahomet laissa autrefois à ses successeurs. Leur recommandant de ne jamais offencer la Monarchie Françoise; parce que leur empire ne seroit jamais ruiné que par la puissance de quelqu'un de ses Roys. Sur ce voulant montrer que l'honneur de ceste conqueste n'appartient point à d'autre qu'à Louys le Juste, nous faisons que la plus part de ces Empereurs en ce tableau luy rendent hommage, en sorte qu'ils contribuent chacun quelque partie de soy pour former son image, comme s'ils se despoüilloient eux-mesmes pour honorer son triomphe".
} 
Figura 3

Jean Niceron. La perspective curieuse [...], prancha XLIX

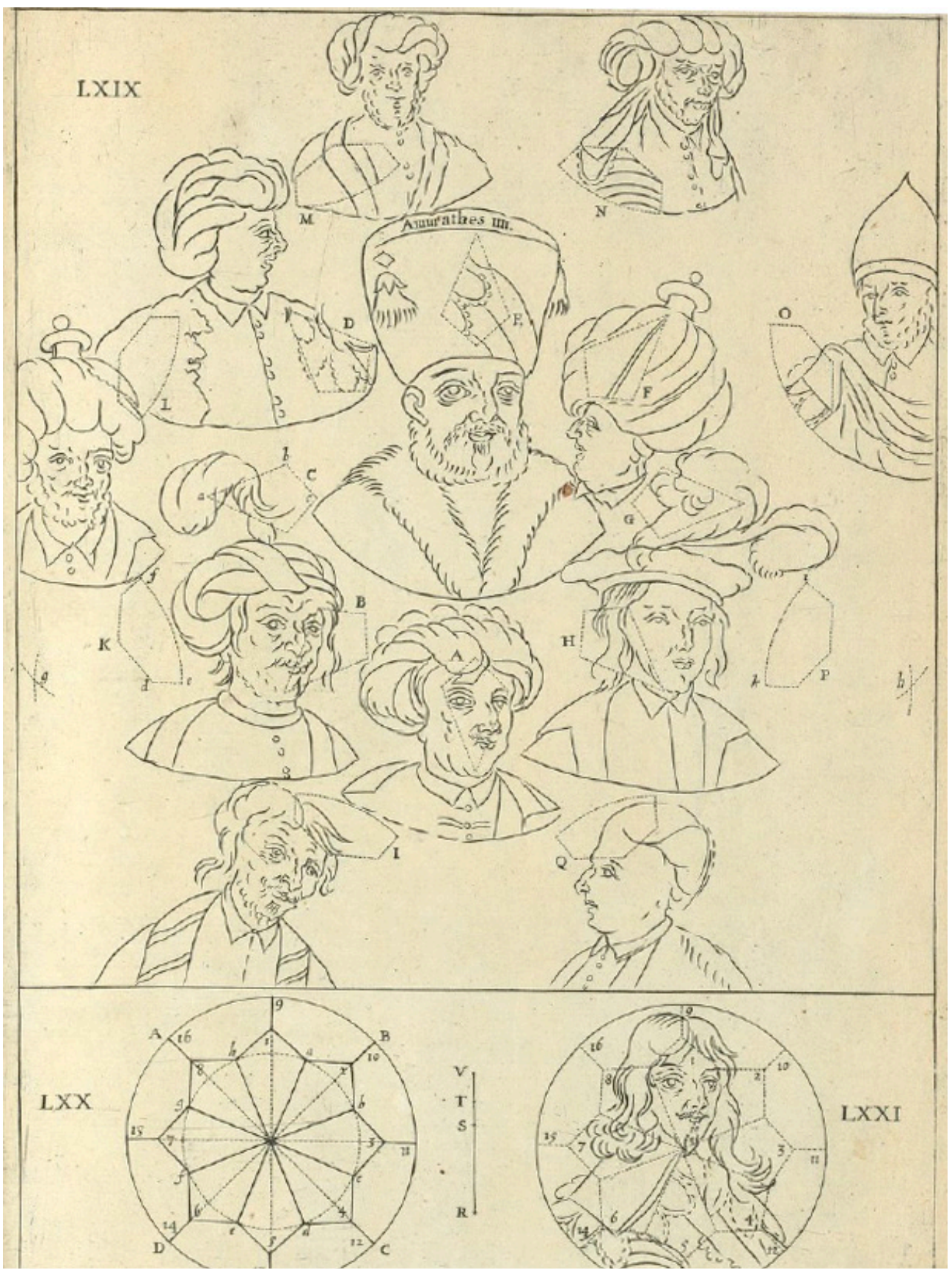

Desenho, 1638. Paris, Bibliothèque Nationale de France. 


\section{Submissão galante}

Não resta dúvida de que Antoine Furetière (1619-1688) tenha sido amplamente versado nas técnicas da disputatio. Elas eram indispensáveis ao ofício de advogado do Parlamento de Paris, posto que ocupou por sete anos, e no bailiado de Saint-Germain de Prés, em que desempenhou a função de procurador-fiscal até conquistar, graças ao abade de Saint-Germain de Prés, o bispado de Chalivoy, no mesmo ano de seu ingresso na Académie, 1662. ${ }^{14}$

A epístola dedicatória ao abade na Nouvelle Allégorique sinaliza para o caráter de sujeição corriqueiro nestes tempos, articulando as atividades letradas e a disputa por poder à proteção de um mecenas. ${ }^{15}$ Mas vai além, dispondo, na enumeração das qualidades do protetor, a política iniciada no fim do século XVI para suprimir as violentas guerras de religião transcorridas nas décadas anteriores. Um momento forte dessa iniciativa teve lugar na sequência do regicídio de Ravaillac, crime de lesa-majestade "humana e divina" - juridicamente um "parricídio", como se lê no acórdão da condenação (ARREST, 1610, p. 1) -, que evoca o temor de desagregação do corpo teológico-político do Estado em voga desde 1562, com o massacre de Vassy, marco do início dos conflitos confessionais.

A punição a Ravaillac é indicativa do grau de violência empregado não apenas para reagir à gravidade do delito, mas para suprimir qualquer desafio à ordem teológico-política afirmada desde o Edito de Nantes, que vetava a própria evocação da memória dos troubles (RODIER, 2019, p. 8). Além da amende honorable na forma de súplicas do condenado ao admitir os atos abomináveis que perpetrou (ARREST, 1610, p. 4), devia ser conduzido a um cadafalso onde seus braços, torso e pernas seriam talhados e cobertos por chumbo fundido; a mão direita, que empunhou a faca usada para assassinar Henrique IV, queimada; seu corpo, desmembrado por quatro cavalos e depois, consumido pelo fogo, ter suas cinzas lançadas ao vento (ARREST, 1610, p. 4).

${ }^{14} \mathrm{O}$ registro consta da Relation da Académie preparada por Paul Pellisson, de 1653 (PELLISSON, 1672, p. 612-613).

${ }^{15}$ Furetière propõe o teatro de sua sujeição apontando, com humilitas, como era indigno de servi-lo, para adiante emendar que seria possível dizer "sem medo, que, não houvesse minha boa fortuna me colocado sob vós, serieis aquele entre todos os Príncipes que teria escolhido para cujo serviço me consagrar inteiramente". "Aussi, MONSEIGNEUR, j'ose dire, que quand ma bonne fortune ne m'auroit pas donné à vous, vous seriez celuy de tous les Princes que j'aurois choisi, pour me consacrer entièrement à son service. Vous estes celuy pour qui j'ay eû toûjours plus de vénération, et dont j'ay trouvé la vertu plus digne d'estre admirée" (FURETIÈRE, 1658, s/p). 
É na contraluz desse crime que se insere o principal dispositivo de louvor de Furetière a seu mecenas. Henri de Bourbon, que, além de abade de Saint-Germain de Prés, era o duque de Verneuil e filho de Henrique IV, seria um dos raros grands a, dotado da nobreza e da coragem dos aptos à liderança em tempos de guerra, "empregar toda a grandeza de sua alma para dominar suas ambições", aplicando-se a "virtudes doces" e a "todos os exercícios Nobres, sem ser sanguinário". Com isso, retomava o que os primeiros cônsules de Roma teriam solitariamente logrado: a habilidade de liderar a república, ou, agora, a monarquia mestra do mundo ${ }^{16}$. Habilidade verdadeiramente única, tornava-o singular perante todos os demais de sua estirpe: "sois o único, SENHOR, cuja aprovação é geral, e que pode dizer que ninguém jamais deixou vossa companhia descontente" (FURETIÈRE, 1658, s/p) ${ }^{17}$.

Ora, a ênfase na singularidade da conduta de Henri de Bourbon mostra mais do que o compromisso político de sujeição, bastante explícito na peroração da carta dedicatória ao postular que aqueles protegidos por ele obtiveram "todas as coisas justas que desejaram e benefícios para além de suas esperanças" ${ }^{\prime \prime}$. Pois, sob o reconhecimento a um patrono aparentemente inabalável, também repousava uma filiação por auctoritas que absorvia o sucesso de uma polêmica anterior, a Querelle des Lettres.

Não foram poucos os livros, epístolas e panfletos publicados na sequência da primeira edição das Lettres de Jean-Louis Guez de Balzac, em 1624, de modo a reagir à exposição pública de um ethos autorrepresentado como unico eloquente. Retomando auctoritates antigas enquanto fingia ignorá-las, Guez de

\footnotetext{
16 "Há bastantes Conquistadores detestados por aqueles que destroem, ao passo que são admirados por aqueles que compartilham suas vitórias; mas há poucos entre eles que, dotados da origem e da coragem capazes de comandar, empenham-se, com toda a grandeza de sua alma, a dominar sua ambição [...]. É assim, SENHOR, que nos tempos de calma e de paz, aplicando-se a todos os exercícios Nobres, sem ser sanguinário, mereceis a glória adquirida pelos primeiros Cônsules de Roma, que na solidão se tornaram dignos de comandar uma República mestra do mundo". "Il y a assez de Conquérans qui sont détestez de ceux qu'ils détruisent, tandis qu'ils sont admirez de ceux qui ont part à leurs victoires; mais il y en a peu qui ayant la naissance et le courage capables de commander, employent tout la grandeur de leur ame, à maitriser leur ambition [...]. C'est ainsi, MONSEIGNEUR, que dans le calme et dans la paix, vous apliquant à tous les exercices Nobles, sans estre sanguinaires; vous méritez la gloire qui ont acquise les premiers Consuls de Rome, qui dans la solitude se sont rendus dignes de commander à une République maistresse du monde".

17 "Vous estes le seuls, MONSEIGNEUR, dont l'aprobation est générale, et qui peut dire que personne n'est jamais sorti mécontent de devant vous" (FURETIÈRE, 1658, s/p).

18 "Au contraire, tous ceux qui ont le bien de vous estre soûmis, ont obtenu toutes les choses justes qu'ils ont desirées de vous, et des bien-faits au delà de leurs esperances" (FURETIÈRE, 1658, s/p).
} 
Balzac afetou um moi logo desdobrado em um "parler Balzac" digno de glória, para alguns, por revitalizar o gênero epistolar satirizando comunicações com grands, como o cardeal Richelieu e o bispo d'Ayre; para outros, era sintoma da transformação do pronome em mecanismo grotesco de rejeição do decoro (MERLIN, 1999, p. 27; 38).

A economia argumentativa das Lettres estribava-se, entre outros procedimentos, na singularização afetada do missivista e de seus protetores. É o que consta na primeira carta do livro, endereçada ao duque de Épernon, Jean Louis de Nogaret de La Valette, cujos méritos administrativos e militares o tornaram conhecido como um "semi-rei" indispensável a Luís XIII. Seguindo à risca o desenho do caráter nobre ao qual queria vincular o nome de Épernon, Guez de Balzac somou os feitos do duque ao valor inerente ao seu nascimento, recordando que seus sucessos decorriam de um estatuto superior, próprio a um dos grands. ${ }^{19}$ Segundo o argumento de Guez de Balzac, era apenas na concórdia entre os dois elementos que a virtude encontraria forças para desencadear feitos que surtissem efeitos entre os pósteros:

Em todo caso, quando considero as ações de vossa vida, que são tais que, mesmo vistas, custa-nos a acreditar que tenham sido realizadas, e em tal número que parece aos estrangeiros que viveis desde o começo de nossa Monarquia, penso poder dizer com verdade que, se ainda há algo grandioso a fazer no mundo, não é necessário haver outro senão vós que o empreenda. ${ }^{20}$

Por trás da independência do "insubmisso" Guez de Balzac, jazia, portanto, um mecanismo persuasivo que alegava sua dependência, etapa de uma arquitetura cujo funcionamento dependia de que os leitores descobrissem, nas primeiras páginas do livro, a auctoritas de alguém de sucesso inconteste por ter sido alcançado exclusivamente na medida das próprias qualidades:

[...] Esta grande autoridade que adquiristes por vosso favor, a mantivestes por meio de vossa coragem. Nas agruras do tempo e da usurpação do poder legítimo, vós conser-

\footnotetext{
19 "Maintenant, Monseigneur, il est temps que vous recognoissiez les auantages que Dieu vous a données par dessus le reste des hommes" (BALZAC, 1624, p. 3-4).

20 "Toutesfois quand ie considere les actions de vostre vie qui sont telles, que nous auons de la peine à les croire apres les auoir veuës, $\mathcal{E}$ en tel nombre qu'il semble aux estrangers que vous viuiez dés le commencement de nostre Monarchie, ie pense pouuoir dire auec verité, que s'il $\mathrm{y}$ a encore quelque chose de grand à faire dans le monde, il ne faut pas que ce soit vn autre que vous qui l'entreprene" (BALZAC, 1624, p. 5).
} 
vastes, absolutamente sozinho, toda a liberdade da França. Quem pode dizer algo assim de si mesmo? ${ }^{21}$

Guez de Balzac almejava uma harmonia inaudita entre a perfeição militar e a nobre autoridade de Épernon e sua combinação, igualmente perfeita, de eloquência e verdade. Estas eram tomadas como o par a ser apropriadamente refletido em seu ethos, ou, em outras palavras, desempenhavam o papel de espelho de seus atributos. É o que ocorre na construção do serviço a Henri de Bourbon, marcado pela afirmação de que entrar em seu círculo de dependência "foi a inveja daqueles que pertencem a outros Mestres"22 (FURETIÈRE, 1658, s/p). Enquanto detalha pacientemente a força irenista irradiada por Bourbon, Furetière põe em marcha uma controvérsia sutil, mas perfeitamente reconhecível entre os primeiros leitores instruídos de sua obra, vestindo a máscara que Guez de Balzac e outros antes de dele ostentaram para se anunciar únicos nos palcos da res publica. Institui-se, assim, a filiação destinada a autorizar o excesso contido das palavras de Furetière por meio da exaltação de qualidades que seu protetor detém por hereditariedade. ${ }^{23}$

Podia-se, nesse sentido, discriminar uma forma aguda de correlação entre autoridade e controvérsia compatível com a bienséance predominante no período, definida por La Mesnardière (La Poétique, 1640) como conduta destinada a prover instrumentos para que se julgasse "como falam as pessoas de condição de seus amores, de suas querelas e de sua civilidade" (MERLIN-KAJMAN, 2012, p. 1). Distinguindo-se entre os discretos, Antoine Furetière preenchia o vazio $^{24}$ de uma representação genérica de si com a finalidade compor uma submissão galante, cuja eficácia fora provada três décadas atrás, e seria novamente testada quatro anos após a morte de Jean-Louis Guez de Balzac.

\footnotetext{
21 “[...] Cette grande authorité que vous auiez acquise par vostre faueur, vous l'auez depuis tousiours maintenuë par vostre courage. Dans les mal-heurs du temps $\mathcal{E}$ l'vsurpation de la puissance legitime vous auez conserué tout seul la liberté de la France. Qui est-ce qui peut dire cela de soy?" (BALZAC, 1624, p. 6).

22 "Leur bon-heur a esté envié de ceux qui sont à d'autres Maistres [...]".

23 "Mas é de fato preciso fazer a enumeração de todas as vossas virtuosas qualidades? Basta dizer que elas vos são hereditárias [...]" (FURETIÈRE, 1658, s/p). "Mais qu'est-il besoin de faire le denombrement de toutes vos vertueses qualitez? Il suffit de dire qu'elles vous sont héréditaires [...]".

${ }^{24}$ Hélène Merlin (1999, p. 40) sugere que a solidão afetada de Guez de Balzac assumiu força de tópica ao longo do século XVII francês, o que se confirma com a presente análise.
} 


\section{Ordens do conflito}

Recorrente em textos alegóricos, a personificação ${ }^{25}$ é basilar na Nouvelle Allégorique, assim como as funções miméticas desempenhadas pelas figuras que compõem o teatro sociocósmico ${ }^{26}$ de posições em controvérsia. Garantir que ambas funcionassem perante o public sem transparecer mala affectatio requereu um esforço considerável. A escrita de Furetière deveria demonstrar conhecimento da geografia do conflito em seus usos de nomes, tipos e episódios, o que, na linguagem do período, definia-se pela expressão sçavoir la carte, isto é, o conhecimento das rotas por onde corriam informações relativas aos bastidores do Estado, segredos, notícias e distinções (BOMBART $\&$ SCHAPIRA, 2004, p. XIV), mas também os diferentes empenhos argumentativos; em suma, a cartografia de tudo quanto concorre para a clara demonstração do conflito, na forma de um quadro estável que movimenta a narrativa a partir de variações pré-determinadas pelas expectativas dos públicos que deveriam consumi-la. ${ }^{27}$

Elas são expostas, de saída, em mecanismos editoriais que esclarecem a hierarquia das personagens e estipulam subtextos mais ou menos explícitos. É o que se percebe na combinação entre as marcas gráficas e profusão de notas marginais que fundem os objetivos de deleite e ensinamento já nas primeiras páginas da Nouvelle Allégorique ${ }^{28}$ :

\footnotetext{
25 "A alegoria (grego allós = outro; agourein = falar) diz b para significar a. A Retórica antiga assim a constituiu, teorizando-a como modalidade da elocução, isto é, como ornatus ou ornamento do discurso. [...] Nesse sentido, ela é um procedimento construtivo, constituindo o que a Antiguidade greco-latina e cristã [...] chamou de 'alegoria dos poetas': expressão alegórica, técnica metafórica de representar e personificar abstrações" (HANSEN, 2006, p. 7).

${ }^{26}$ A definição figural pressuposta nas alegorias justifica-se, de resto, pela própria definição de "alegoria" disponível no Dictionnaire que Furetière fez imprimir em 1690: "Alegoria. Substantivo feminino. Figura de Retórica, é uma metáfora continuada, quando nos servimos de um discurso que é próprio a uma coisa para fazer entender, com ela, outra. O Velho Testamento é uma perpétua Alegoria dos mistérios contidos no Novo" (FURETIÈRE, 1690, p. 78). "Allegorie. Subst. fem. Figure de Rhétorique, est une metaphore continuée, quand on sert d'un discours qui est propre à une chose pour en faire entendre une autre. Le Vieux Testament est une perpetuelle Allegorie des mysteres contenus dans le Nouveau".

${ }^{27}$ Mathilde Bombart e Nicolas Shapira sugerem que, ao contrário de outros textos do gênero, cada vez mais recorrente a partir dos anos 1650, a Nouvelle Allégorique não teria sido construída como uma "imagem fixa", mas como uma narração (BOMBART \& SCHAPIRA, 2004, p. VII).

${ }^{28}$ Lembremos, com Lucia Calboli Montefusco (1988), que o exórdio de textos em registro médio, caso da Nouvelle Allégorique, sustentava-se no tripé "informar, manter atento, tornar benévolo", privilegiando, ainda, a persuasão pelo ethos. Diante disso, não espanta a profusão de descrições
} 
A Sereníssima Princesa RETÓRICA a reinava pacificamente há muitos séculos, e seu governo era tão doce, que ela era obedecida sem dificuldade. Não praticava qualquer violência contra seus súditos, senão lhes enviar seu grande Emissário chamado Persuasão, com uma companhia de belas Palavras, seus Arqueiros [...] (FURETIÈRE, 1658, p. 1-2).29

O uso de nomes em caixa alta é infrequente no livro, servindo de marca distintiva imediatamente superior ao itálico - este reservado sobretudo às personagens ativamente engajadas na guerra, embora funcione, ainda, como recurso de ênfase (État, Reine, etc.) - e maiúsculas, flagradas nos títulos militares, a exemplo de Prévost ${ }^{30}$, ou nos nomes das figuras (Persuasion, Équivoques, Allusions etc.). As notas remetem à marginália. No caso citado, a nota "a", acoplada ao termo "RETÓRICA", diz: "Trata-se da arte da Eloquência, ou do bem

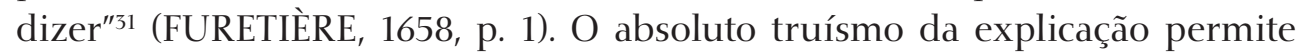
considerá-la indício da interposição joco-séria de, por um lado, notas informacionais $^{32}$, que efetivamente elucidam nomes, textos, instituições, e, por outro, as que satirizam a erudição escolar através da evocação de escólios inúteis que contrapõem o mundo "honesto" dos homens de letras mondains à futilidade dos saberes "doutos" (BOMBART \& SCHAPIRA, 2004, p. XXII).

Furetière estabelece a autoridade da princesa Retórica na longa duração dos usos das técnicas retóricas, atrelando-a às garantias institucionais propiciadas pela adesão à Académie. Na sequência da introdução de seu "ministro", chamado "Bom Senso", relata-se que a princesa estava cercada de oficiais voltados tanto para a proteção de seu reino quanto para a "polícia" dele, zelando pela obediência dos súditos. A expressão máxima da tendência ao controle político das gentes figuradas é a organização de seu "conselho sobe-

das figuras, as ponderações sobre sua honestidade e engenho, que, de resto, prolongam a expectativa pelo embate.

29 “La Sérenissime Princesse RHETORIQUEa reignoit paisiblement depuis plusieurs siecles $\mathcal{E}$ son gouvernement étoit si dous, qu'on luy obeïssoit sans contrainte. Elle ne faisoit point d'autre violence à ses sujets, que de leur envoyer son grand Prévost nommé Persuasion avec une compagnie de belle Paroles ses Archers [...]."

${ }^{30}$ Traduzido aqui por "Emissário" diante das informações disponíveis no Dictionnaire de Furetière, que assinala, entre outras possibilidades, "um grande Oficial nas Ordens Militares" (FURETIÈRE, 1690, p. 1669). "un grand Officier dans les Ordres Militaires".

31 "C'est l'art de l'Eloquence ou du bien dire".

${ }^{32}$ Para exemplo, veja-se o termo Polyanthéa (FURETIÈRE, 1658, p. 14), que remete, simplesmente, a uma explicação de ordem informacional: "trata-se do título de um grande Dicionário ou Compêndio de lugares-comuns, em que são reunidos, por ordem alfabética, as passagens de diversos autores sobre toda sorte de matérias" (FURETIÈRE, 1658, p. 14-15). "C'est le titre d'un gros Dictionnaire, ou Recueil de lieux comuns, où sont ramassez par ordre alphabetique les passages de plusieurs autheurs sur toutes sortes de matieres". 
rano", situado na Academia. Grafada em maiúsculas, como o próprio nome da princesa, é definida no corpo principal do texto como grêmio de quarenta "Barões", tidos por "confidentes" do governo, os quais detinham "quase toda a autoridade nas mãos" ${ }^{\prime \prime 3}$, reunindo-se semanalmente para discutir os assuntos do Estado e, em particular, a elaboração de um censo de seus habitantes, por meio de um Dicionário (FURETIÈRE, 1658, p. 2-3). Ao mesmo tempo, a passagem remete à notação lateral "b", que alude às concretudes institucionais da corporação pública em sua origem: "Trata-se de uma assembleia de 40 dos mais ilustres escritores do século. Fundada em Paris pelo Senhor, Cardeal de Richelieu para cultivar a língua Francesa, ela se reúne duas vezes por semana na residência do Senhor Chanceler"34 (FURETIÈRE, 1658, p. 3).

As referências transportam a autoridade das figuras para as mãos de um mecenas específico de modo a registrar as volumosas benesses obtidas graças ao seu auxílio, movimento relativo à fragilidade do sistema de pensões após a morte de Richelieu, o que acarretou maior dependência em relação às agendas dos livreiros impressores. ${ }^{35}$ Nesse ínterim, a dependência aristocrática dos grands e dos aparatos de Estado passou a servir de caução à "independência" dos escritores frente a pressões de mercado. ${ }^{36}$ A perspectiva é confirmada pela ideia, recorrente no período, ainda que desprovida de validade empírica (ROSSELLINI \& VIALA, 2015, p. 14-15), de um crescimento indomesticável da impressão de obras.

Letrados como Jean Oudart de Richesource responsabilizavam a imprensa por esses males nas suas Conférences académiques em 1665. Se ela fora criada com finalidade nobre, isso não se podia dizer de seus usos naqueles anos, quando teria passado à condição de máquina sombria de corrupção

\footnotetext{
33 "Son conseil souverain résidoit dans ACADEMIE, sa ville Capitale, \& étoit composé de quarante Barons confidens de la Reine, qui avoient presque toute l'authorité em main."

34 "C'est une assemblée de 40 des plus ilustres écrivains du siècle, fondée à Paris par Monsieur le Cardinal de Richelieu, pour cultiver la langue Françoise, elle s'assemble deux fois la semaine chez Monsieur le Chancelier".

${ }^{35}$ As consequências da morte de Richelieu são referidas explicitamente na Nouvelle Allégorique (FURETIÈRE, 1658, p. 131), como se verá adiante.

${ }^{36}$ Não se deve perder de vista que este momento assiste à ascensão de mestres impressores de alto apuro técnico não necessariamente acompanhado de erudição livresca, para não mencionar os casos em que se denuncia a imprecisão de tipógrafos, corretores e compositores (CHARTIER, 2020, p. 27). O tema mostrou-se relevante durante a fundação da Académie, quando se notou a dificuldade de encontrar um impressor adequado; a escolha acabou recaindo sobre Jean Camusat, um dos poucos profissionais a comercializar livros raros e gozar da formação livresca típica do início da segunda metade do século XVI e início do XVII (CHARTIER \& MARTIN, 1989, p. 477-483).
} 
dos costumes. ${ }^{37}$ A própria materialidade dos textos repercutia esse estigma, pois a proliferação desmedida vinha acompanhada de impressões defeituosas e crivadas de erros. Para descrever esse estado de coisas, Richesource mobilizou a tópica da indigestão causada pelos livros contemporâneos perante a "boa alimentação" proporcionada pelo comércio com as "mercadorias" realmente excelentes.

Charles Sorel (1602-1674), um dos letrados mencionados na Nouvelle Allégorique, salientou, em diversos livros (sobretudo em sua Bibliothèque Françoise, de 1667), a dificuldade de escolher e comprar boas obras entre as centenas com que se confrontava diariamente nas livrarias. Para ele, o problema era sobretudo de ordem intelectual. A profusão de livros indicaria o rebaixamento do engenho coletivo, o que correspondia à impossibilidade de conquistar a autoridade imortal despertada pela emulação eficaz dos antigos. É com eles que enfatizará o poder da leitura e da escrita de remediar as doenças do corpo político. Na metáfora que apresenta, um bom livro seria como o cajado de Moisés que destruiu as serpentes conjuradas pelos magos do faraó. Sorel se autorrepresenta como um "censor" de livros, complementando o trabalho da Chancelaria no tempo de Richelieu. Além disso, retomava uma metáfora usual naquele universo, fazendo-se de apotecário dos saberes; Sorel sugeria ser necessário agir como os médicos, "que ordenam o gênero e a quantidade de fármacos necessários a cada um”, procedimento semelhante ao de compor listas de livros tidos por excelentes.

Ao acusar as próprias prensas de erodir a "república das letras", os letrados das décadas de 1650 e 1660 partiam de dois princípios táticos que se fazem sentir nas primeiras páginas da Nouvelle Allégorique: primeiro, justificar a relevância da Académie - e de livros de "arquivamento" do que é digno das expectativas da posteridade, mas também pela profusão de "Bibliotecas" e "Dicionários" no período - por sua capacidade de inventariar e selecionar; segundo, assegurar o monopólio da "multiplicação dos livros" (ROSSELLINI \& VIALA, 2015, p. 13), fazendo com que esta só fosse legítima nos momentos em que, por exemplo, controvérsias decorosas se fizessem necessárias. Nesse sentido, a alegoria de Furetière participava do fortalecimento do próprio gênero controversia e do sistema de reconhecimento devido àqueles que, dignos

\footnotetext{
37 Saliente-se que esta posição estava longe de ser unívoca. Outros, como Charles Sorel, preferiam atacar o crescimento do volume de livros impressos pelo enfraquecimento intelectual dos textos (ROSSELLINI \& VIALA, 2015, p. 15).
} 
de ocupar o topo da hierarquia social, prestam bons serviços e peticionam recompensas equivalentes a seus méritos (PÉCORA, 2001, p. 124-125).

O curto-circuito da lógica de reconhecimento, em suas implicações morais e teológico-políticas, serve de estopim para as hostilidades narradas por Furetière. Tudo teria começado de forma bastante singela, desencadeando uma tempestade a que Retórica com muito custo sobreviveu. Em sua reforma das milícias do reino, o ministro Bom Senso dispensou as tropas de Équivoques; conhecidas por sua "licenciosidade", traziam troubles ao Estado e revestiam-se de duplicidade, "pois diziam uma coisa e faziam outra"38 (FURETIÈRE, 1658, p. 6). Desempregadas, teriam achado socorro na região do Pedantismo, cuja metrópole era o Ginásio (isto é, os Collèges), onde impera a confusão que reflete o episódio babélico, à "exceção de uns poucos cantões, que se preservaram da corrupção geral"39 (FURETIÈRE, 1658, p. 7).

Para além da especificidade do termo trouble como marca das guerras confessionais, os Équivoques encenavam satiricamente o ambiente de perseguição aos libertinos e as querelas desencadeadas por sua ação; no quadro verossímil de referências do período, é possível que a "corrupção" dos Équivoques beneficiasse do caso paradigmático de Théophile de Viau (VAN DAMME, 2008 p. 56-57), preso e condenado pela suposta publicação de poemas libertinos, mas também as denúncias de religiosos contra Guez de Balzac, calcadas no caráter ambíguo de sua apresentação social, na convergência paradoxal de decoro e desregramento, assim como na corrupção dos saberes eruditos, degenerados pelo espaço letrado mundano. Finalmente, eles sinalizavam para uma duplicidade ainda mais perniciosa: o risco de falsa conversão de huguenotes, abrigados pelo uso sofista das palavras.

A "polissemia não resolvida"40 visível na oscilação entre dissimulatio honesta, gracejo agudo próprio da conversação cortesã, e dolus malus (MISSIO, 2012, p. 96-99) - imprudência, inconstância, desarmonia alegorizadas com a presença dos Équivoques - prepara a entrada do antagonista, o capitão Gali-

\footnotetext{
38 "[...] outre cela, ayant une certaine ame double dont il se falloit défier, car elles disoient d'un, et faisoient d'autre".

39 "[...] si on en excepte pourtant quelques petits cantons qui se sont preservez de la corruption generale".

${ }^{40}$ Lançar mão dos equivoques era prática central entre os letrados como Furetière e Guez de Balzac, dotando-os de ferramentas para, no contraste impossível entre dois termos ou dois ethe incompatíveis, privar os leitores de uma escolha definitiva (NÉDÉLEC, 2004, p. 17). O gênero de disputatio deflagrado por eles dependia, portanto, da recepção das matérias que compunham - moral, extraindo-se da Ética a Nicômaco e do De Officis, por exemplo, ou jocosa, apostando na ressonância com as doutrinas da agudeza e da dissimulação como virtude civil.
} 
matias. ${ }^{41}$ Homem "obscuro", "nascido da arraia-miúda", teria feito prevalecer a desonestidade de uma "má inteligência" para tornar-se mestre do território pedante, abrigando as tropas desertadas da Retórica sob seu mecenato. Ao aliar-se, pelas mesmas razões, também às Allusions, entre outros "malcontentes" no ódio imemorial à Retórica e ao Bom Senso (FURETIÈRE, 1658, p. 9), o capitão tornava-se por excelência refúgio de vulgares e, na visualização da alegoria, a cabeça de um corpo efetivamente monstruoso.

Essa combinação de vulgaridade e inconstância está inscrita na definição genérica de "povo" do célebre tratado de Pierre Charron, De la sagesse. Ao contrário dos nobres, que dependeriam da conjunção entre nascimento e ações virtuosas para alcançar a sabedoria, a única saída para aqueles que pertencessem ao povo seria resignar-se à condição selvática de "inimigos dos virtuosos", seres afinados à instabilidade e ao desvario, almas cuja inconstância imprudente apartava da imortalidade:

O povo (fala-se aqui do vulgo, da multidão e da arraia-miúda, gentes, desde qualquer ângulo que se veja, de baixa e mecânica condição) é uma besta monstruosa de muitas cabeças, e que não se pode descrever bem em poucas palavras, sendo inconstante e volúvel, não mais estável que as ondas do mar. Ele se insurge e se amansa, aprova e reprova a mesma coisa num instante. Não há nada mais fácil do que conduzi-lo a qualquer paixão que se queira; ele não ama a guerra por sua finalidade, nem a paz por seu conforto, senão que, indo de uma à outra, haja sempre mudança ${ }^{42}$ (CHARRON, 1601, p. 256-257).

A oposição leva a que dois corpos políticos e linguísticos se formem, prestes batalhar ao abrigo do riso sem dor que apazigua as dores muito concretas a que remetem. ${ }^{43}$ Para além do resíduo de conflitos empíricos e da

\footnotetext{
${ }^{41}$ O Dictionnaire de Furetière propõe que galimathias é todo "discurso obscuro e confuso, em que nada se compreende" ("discours obscur et embrouillé où on ne comprend rien"). O termo também alude a situações tormentosas, "e casas em desordem", onde maridos contra esposas e filhos contra pais produzem um galimathias, isto é, uma polymathie às avessas. O último exemplo da entrada menciona a Nouvelle Allégorique: "A Nouvelle Allégorique relata um combate engenhoso de Galimathias contra a razão" (FURETIÈRE, 1690, p. 934). "La Nouvelle Allégorique rapporte un combat ingenieux de Galimathias contre la raison".

42 "Le peuple (nous entendons icy le vulgaire, la tourbe $\mathcal{E}$ lie populaire, gens soubs quelque couuert que ce soit, de basse seruile $\mathcal{E}$ mecanique condition) est vne beste estrange à plusieurs testes, $\mathcal{E}$ qui ne se peut bien descrire en peu de mots, inconstant $\mathcal{E}$ variable, sans arrest non plus que les vagues de la mer; il s'esmeut, il s'aacoyse, il approuue $\&$ reprouue en vn instant la mesme chose; il n'y à rien plus aise que le pousser en telle passion que l'on veut; il n'ayme la guerre pour la fin, ny la paix pour le repos, sinon etant que de l'vn à l'autre il y à tousjours du changement."

43 "Segundo preceptistas do século XVII, a sátira é um subgênero do cômico - o que não a faz necessariamente engraçada, porém, uma vez que o ridículo, que no cômico é a inconveniên-
} 
aposta em controvérsias galantes, o texto decreta o papel hierárquico desempenhado pela Académie ao postular o direito de escolher a quem compete fazer uso digno das Letras. A despeito das inimizades descritas, a declaração de guerra é consequência direta do rompimento do "comércio" e a desvalorização de todas as "moedas" e "mercadorias" vindas da região do Pedantismo. Tendo enviado, sem sucesso, um arauto às terras de Retórica, Galimatias não vê outra saída senão arregimentar suas comissões para, com elas, absorver o "partido" inimigo (FURETIÈRE, 1658, p. 10). O butim mais valioso a recolher nesta guerra era, portanto, o da adesão.

\section{Figuras da autoridade}

Desse ponto em diante, o livro se volta para écfrase detalhada das forças. Ironias, sarcasmos, antíteses, metáforas, alegorias, prosopopeias, anagramas, comparações, sermões, épicos, idílios, epifenômenos, hipérboles, além de "Autoridades incontáveis" - a maior força do exército de Galimatias (FURETIÈRE, 1658, p. 14) - são apenas algumas das figuras descritas. Arregimentavam-se sob o comando dos índices, que iam atrás das tropas para que não perdessem o sentido, e de Polyanthéa, o dicionário de lugares-comuns que evitava a "confusão" arranjando-as em ordem alfabética. Para diferenciá-las dos exércitos de Retórica, Furetière lembra que as figuras associadas a Galimatias, de modo geral presentes em ambos os lados, eram mais ou menos partícipes do populacho, comungando vulgaridades. Embora proliferassem autoridades greco-romanas nas hostes de Galimatias, estas eram versões "barulhentas" e pesadas de erudição baldia, ao contrário das que se mantiveram ao lado do partido virtuoso, nobres, limpas e saudáveis: “O que havia nisto de notável é que cada Autoridade era obrigada a ter, ao se alistar, um boletim de saúde para marcar o lugar de onde vinha"t44 (FURETIÈRE, 1658, p. 16).

As marcas de autoridade atendiam a regras de clareza, proporção e conveniência; propiciavam reconhecimento a partir da atualização do que é eficaz, multiplicando relações de semelhança naturalizadas como deslo-

cia que faz rir sem dor, nela é maledicência. Por ser mista, opera com metonímias recortadas de vários discursos, vozes, léxico e procedimentos, não tendo a pureza prescrita em outros gêneros" (HANSEN, 2004, p. 88-89).

${ }_{44}$ "Ce qui se trouvoit icy de remarquable, c'est que chaque Authorité étoit obligée en venant s'enrôler, d'avoir un buletin de santé, pour marquer le lieu d'où elle venoit". 
camento comparativo e metafórico do que Furetière emula. ${ }^{45}$ Isso explica a ênfase em "índices" e "dicionários", além do próprio modo de descrever as tropas, que, recorrentemente explicadas pelas notas, mesclam o próprio e o figurado com alto grau de abertura da significação (HANSEN, 2006, p. 81). Porém, isto não deve nos afastar da identificação do caráter "imperfeito"46 do conjunto das alegorias propostas por Furetière, isto é, o grau de difração das matérias empíricas de que trata.

Tal operação permite-nos caracterizar dois dispositivos de autoridade da Nouvelle Allégorique: primeiro, o sistema de emulação calcado no juízo do que está de acordo com as auctoritates reconhecidas por Furetière e as deformações satíricas que faz delas. O controle assim efetuado aparece no texto com a menção a places de seuretét ${ }^{47}$, concebidos como locais de tolerância às práticas de certas figuras. Em segundo lugar, ao aproximar determinados grupos figurativos a autoridades letradas - os corpos de Comparações, por exemplo, são comandados por Lycosthenes, conhecido, como o próprio livro explica, pelo repertório de lugares-comuns que fez imprimir no século XVI - dava-se origem a um sistema de correlações "impossível de desfazer no todo" (FURETIÈRE, 1658, p. 18) porque garantido pela presença de lugares-comuns que transitam livremente entre os campos de batalha. ${ }^{48}$

\footnotetext{
45 "Quanto à convenção de clareza, efetuava-se através dela uma espécie de preestabelecimento da cognição do ouvinte articulada na própria ordem do discurso, de tal modo que, na 'facilidade' de compreensão do que era dito, o ouvinte reconhecia a prescrição de um bom desempenho" (HANSEN, 2006, p. 46).

${ }^{46}$ Entenda-se por "imperfeição" o subgênero de "alegorias imperfeitas", definido por Cícero como influxo do próprio no figurado com a finalidade de engendrar um discurso tão evidente quanto ornado. "Nela, como fica evidente, a mistura do próprio e do figurado está a serviço da clareza e, por isso, é tida como mais didática. Observe-se que o atributo 'imperfeita' não se refere a uma forma defeituosa ou ao mau funcionamento, mas ao grau de abertura da significação, quando comparada com o enigma ou tota allegoria. Por isso, a alegoria imperfeita é recomendável, segundo a Retórica antiga. Quintiliano a cita como causa de belos discursos a um tempo claros e agradavelmente ornamentados" (HANSEN, 2006, p. 66).

${ }^{47}$ A expressão aludia, ainda, às cidades cujo comando militar ficava nas mãos de um protestante como consequência das tratativas que acarretaram o fim oficial das hostilidades contra os católicos (BOMBART \& SCHAPIRA, 2004, p. 50).

${ }^{48} \mathrm{O}$ modelo vale para todo o exército; pode-se dizer, então, que as tropas de Retórica "[...] eram, em maioria, de mesma natureza do que aqueles a serviço do campo inimigo, porém mais bem disciplinadas e aguerridas" (FURETIÈRE, 1658, p. 35). "étoient la pluspart de méme nature que celles qui servoient dans le Camp ennemy; mais mieux disciplinées \& mieux aguerries". A ideia é reiterada logo adiante, quando se diz que "[...] quase todas as tropas vistas no Campo inimigo, a Rainha as tinha no seu, em menor número, mas em melhor ordem" (FURETIÈRE, 1658, p. 40). "[...] presque de toutes les troupes qu'on voyait dans le Camp ennemi, la Reine em avoit dans le sien, en plus petit nombre, mais en meilleur ordre".
} 
Um exemplo particularmente relevante da simbiose entre movimento e estabilidade das figuras vem da associação das Hipérboles, corpos de cavalaria, ao "Príncipe Balzac a"49. Caracterizadas como distorções fantásticas do natural, fizeram grandes estragos sob a tutela de Guez de Balzac, que queria, com seu auxílio, desposar Retórica à força. Entretanto, tendo sido abandonadas por ele quando "fez sua paz com ela", aliaram-se a outros, que "as levaram mais longe, conduzindo-as até chegarem aos confins do país da Extravagância"50 (FURETIÈRE, 1658, p. 21).

Na ação desses "temerários aventureiros" deposita-se um conjunto difuso de referências àqueles que, estimulados pelo sucesso das Lettres, "esforçaram-se para imitá-lo". Mas é verossímil que o alvo primário do vitupério tenha sido o principal querelante a investir contra Guez de Balzac, Jean Goulu, responsável pela publicação da Premiere partie des Lettres de Phyllarque a Ariste, impressa por Nicolas Buon em 1627. Neste livro, "Phyllarque" é constituído como representante do Collège Royal disposto a ensinar o "jovem Ariste" a não incorrer nos erros perversos de "Narcisse", isto é, Guez de Balzac, a partir do mesmo gênero de exageros e afetações perniciosas. Um dos principais mecanismos de demonstração das teses de Phyllarque é precisamente expor as autoridades ocultadas por Guez de Balzac, fazendo ver que, por trás da artificialidade da construção do unico eloquente, jazia a "verdadeira conformidade" dos lugares-comuns públicos de que todos se valiam. Assim, passagens de Guez eram confrontadas de forma escolar com os loci de onde eram extraídas. Por exemplo: se "B" [Balzac] diz "Reunir as duas coisas mais raras do mundo, a saber, a verdade e a eloquência", é preciso revelar a passagem "Duas res pulcherrimas eloquentiam \& veritatem simul conservans", tirada de Sêneca (GOULU, 1627, p. 501).

Por outro lado, as cartas de Goulu foram consideradas caricaturas pseudo-eruditas do parler Balzac, pois, primeiro, amparavam-se em um registro cujo didatismo se aproximava do modelo "erudito" fortemente criticado como

\footnotetext{
${ }^{49}$ A nota "a" refere de modo cristalino o contexto empírico da referência: "entenda-se com isso as primeiras cartas de Balzac, nas quais ele havia inserido hipérboles demasiadamente frequentes e excessivas" (FURETIÈRE, 1658, p. 21). "Cela s'entend des premières lettres de Balzac, où il avoit mis des hyperboles trop frequentes et trop excessives".

50 "Ce fut lors que certains avanturiers qui s'étoient éforcez de le contrefaire, luy succédérent pour leur commander, qui leur enflant le courage les poussérent encor plus loin que luy, et les menèrent jusqu'aux confins du païs d'Extravagance".
} 
pedante, além de recorrer a paródias que transformavam as Lettres em um livro "monstruoso", inclusive mesclando passagens dela a textos de outros "aliados" de Guez de Balzac (BOMBART, 2007, p. 328-329). Nesse sentido, se "derrotava" seu adversário provando a pirataria caracterizada pelo sequestro de lugares-comuns antigos, equivalia-se a ele nos modos polêmicos de expressão. De fato, entre 1628 e 1630, momento mais agudo da controvérsia, a discussão derivou em definitivo para os procedimentos ligados à disputatio mundana $^{51}$, e é este o registro que prevalece, em forma amplificada, na Nouvelle Allégorique: um "partido" desproporcional, pitoresco, datado, combinando a elocução das Lettres de Guez de Balzac e as correções deformantes de Jean Goulu $^{52}$, e outro, porto de todos os usos justos e medidos das palavras, independentemente das posições empíricas dos letrados envolvidos na querela.

Verifica-se, portanto, reciprocidade entre dois níveis alegóricos, e não mera transposição de eventos históricos. As imagens evocadas por Furetière aderem à posição vitoriosa do ponto de vista do decoro letrado cuja prática defende na própria formatação de sua história dos troubles. Considerando-se que a controvérsia em torno das Lettres de Guez de Balzac levou a que os partidos perdessem a medida das hipérboles, deve-se, nos tempos de relativa estabilidade desde criação da Académie, vituperá-las a despeito de quem as manuseie, denunciando seu uso artificioso e desproporcional, o que, nas latitudes da alegoria de Furetière, se reflete na decisão de Balzac de desposar a Retórica mediante os instrumentos da paz, livrando-se dos "exageros" para encontrar acolhida junto ao "bom partido"53 (FURETIÈRE, 1658, p. 39).

É a mesma relação geral do "gosto" galante que prevalece nas exortações à batalha pronunciadas por Galimatias e Bom Senso. A arenga de Galimatias ocupa cerca de seis páginas do livro, exemplificando em abundância os arroubos de uma fala desmedida que incita as figuras sob seu comando a abandonar as posições (places de seureté) que o costume lhes atribuiu:

\footnotetext{
${ }^{51}$ Isto é, em torno das "[...] formas e instâncias legítimas, de um ponto de vista simbólico e social, do discurso crítico e letrado [...]" (BOMBART, 2007, p. 364). "[...] des formes et des instances légitimes, d'un point de vue symbolique et social, du discours critique et lettré".

52 Isso se confirma na narrativa do ataque "inumano" sofrido pelo príncipe Balzac, "um dos mais temíveis combatentes", por uma "multidão" (termo, como vimos, pejorativo) composta por uma série de letrados envolvidos na Querelle des Lettres, entre eles o Père Goulu (FURETIÈRE, 1658, p. 145-146).

53 "Le Prince BALZAC luy envoya aussi quelques Régimens d'Hyperboles, qui l'avoient suivi quand il s'étoit remis dans le bon parti [...]".
} 
"[...] Sinto-me assim estimulado por uma Autoridade tão decisiva [Aléxander Macédo] de insuflar os foles de meus pulmões para iluminar, com seu hálito, a forja de vosso coração, e imprimir vossa coragem candente com o desejo de glória. Não que eu não saiba que vosso Entusiasmo fulminante tenha chamas assaz vivas para consumir, com uma única centelha, as Regiões Hiperbóreas [...]. Já houve um dia Monarquia universal senão a nossa? E desse grande globo sublunar que os minuciosos Geômetras dividiram em trezentos e sessenta partes, não possuímos ainda trezentas e cinquenta e nove delas? [...] $O$ que não devemos esperar de nosso número, que se encontra, em proporção, mais que cêntuplo do exército do persa Mastigothalasse [Xerxes]? [...] O que farão frases estropiadas com Vocábulos atenuados, e em maioria feminizadas, quando forem atacadas por termos fortes e robustos como Eautontimoroumenos Amphitrioníades? Sincathegorimatices? E outros Polifemos Endecassilábicos? Avançai, Equívocos e Alusões de que Retórica quis fazer o Ostracismo, vamos vingar vosso banimento? [...] E vós, Comparações e Autoridades, não estais em sofrimento porque ela vos reteve prisioneiras, sem que pudessem sair sem sua licença de vossos lugares-comuns? (FURETIÈRE, 1658, p. 79-83).54

Em contrapartida, Bom Senso faz discurso conciso, proclamando a defesa da "razão" contra a insurgência da turba de "bárbaros":

Como apenas o desejo de glória vos põe hoje de armas em mão, é desnecessário um grande discurso para vos incitar a mostrar valor [...]. Jamais se apresentou uma ocasião tão ilustre de defender a Razão oprimida pela Barbárie. O século revolta-se contra nós, é certo, e nossos Inimigos estão em grande número, mas lembremo-nos de que os Gregos e os Romanos, que nos ensinaram a combater, sempre estiveram em vantagem contra os Bárbaros [...] (FURETIÈRE, 1658, p. 85-86). ${ }^{55}$

Se ambas as exortações convocam a sabedoria dos antigos, apenas Bom Senso a manifesta em gravidade solene, relegando a Galimatias o acordo com "autoridades" fantasmáticas, cujos desvarios são estimulados mediante com-

\footnotetext{
54 "Ainsi je me sens stimulé par une authorité si décisive, d'enfler les soufflets de mes poulmons, pour allumer par leur haleine la forge de vostre coeur, et rendre vostre courage tout bruslant du desir de gloire. Non que je ne sçache que vostre Enthousiasme foudroyant; ait d'assez vives flammes pour consommer d'une seule étincelle les Régions Hyperborées [...]. Y a-t-il jamais Monarchie universelle si ce n'est la nostre? Et de ce grand globe sublunaire que les Géometriciens pointilleux divisent en trois cens soixante parties, n'en possédons-nous pas encore trois cens cinquante neuf? [...] Que ne devons-nous point espérer de nostre nombre qui est em proportion plus que centuple de l'armée du persan Mastigothalasse? [...] Que feront des phrases estropiées avec des Vocables adoucis et la plus part feminisez, quand ils seront attaquez par des termes forts et robustes comme Eautontimoroumenos Amphitryoniades? Syncathégorématices? Et autres Polyphémes Endecassyllabiques? Sus donc Equivoques et Allusions dont la Rhétorique a voulu faire l'Ostracisme, allons vanger vostre banissement? [...] Et vous, Comparaisons et Authoritez, ne souffrez pas qu'elle vous retienne prisonnieres et que vous n'osiez sortir sans son congé de vos lieux communs?"

55 "Puis que le seul desir de gloire, vous met aujourd'huy les armes à la main; il n'est pas besoin d'un grand discours pour vous exciter à monstrer de la valeur [...]. Jamais [il ne s'est presenté] une plus belle occasion de défendre la Raison opprimée par la Barbarie. Le siecle est revolte contre nous, il est vray, et nos Ennemis sont en grand nombre, mais souvenons nous que les Grecs et les Romains, qui nous ont appris à combattre, ont toûjours eû avantage sur les Barbares".
} 
parações que denotam imperícia cômica. Embora refira-se a "Alexandre Macedo", o exército que ampara sua "monarquia universal" deriva diretamente de uma comparação com as forças de Xerxes, postas em analogia com a profusão de livros inconsequentes num século insurgido contra a autoridade verdadeira. Essa correlação é confirmada no primeiro movimento da guerra, quando o batalhão das Antíteses, repleto de inimizades "mortais e capitais", "oposições e contrariedades em todas as suas fileiras", enche-se de ódio ao ouvir os instrumentos militares e começa a lutar consigo mesmo, desfazendo-se sem que Galimatias pudesse "prever tal desordem" (FURETIÈRE, 1658, p. 88-89). Até mesmo as Hipérboles, cheias de "orgulho natural", tornam-se, contra as aparências de robustez, "Fantasmas cheios de vento" (FURETIÈRE, 1658, p. 92). O príncipe foi o único a não se quebrar perante tamanho desastre, pois estava cercado por sua guarda pessoal, os Equívocos, armados com lanças que não foram rompidas pelo avanço de Retórica (FURETIÈRE, 1658, p. 94) - mas que, poderíamos supor, também o impediam de ver.

Eis o motivo de Bom Senso encerrar sua alocução convocando os auspícios do "nosso ilustre PROTETOR", ou, como se informa em nota, o chanceler da Académie, Pierre Séguier. A referência é crucial, pois sinaliza para a relação de mecenato calcada no controle dos livros, papel que Séguier cumpriu sob a direção de Richelieu. Firma-se, com ela, o pacto celebrado pela soma dos episódios narrados na Nouvelle Allégorique: a auctoritas não é o resultado de guerras letradas; estas são, na verdade, formas de comemoração de um processo prévio de escolha de papéis dignos de serem lidos, das formas apropriadas de querelar, do filtro exigente de letrados - Séguier foi, afinal, o destinatário de muitas epístolas dedicatórias (BOMBART \& SCHAPIRA, 2004, p. 55) - e dos poderes monárquicos que os uniam na qualidade de um corpo dotado de um único e só objetivo: redigir, através de figuras polêmicas em cena, cartas aos pósteros calcadas em um savoir-faire confirmado a priori.

A comemoração do arquivamento dos conflitos é comentada por Furetière ao narrar a divisão estabelecida entre os líderes do reino de Retórica (isto é, os membros da Académie) enquanto debatem estratégias para reagir a Galimatias. Ela é tanto um imperativo do jogo letrado quanto do ato de fixar as disputas em impressos. "A divisão se impôs entre os Chefes, mesmo entre os Conselheiros, que por vezes querelavam em pleno Conselho", diz; "esses diferendos eram imortais, pois, quando diziam injúrias uns aos outros, dirigiam-se à Posteridade, sua Confidente; e, não obstante, eles nada disso podiam desdizer, pois sua marca e Impressão se impunham para sempre" (FURETIÈRE, 1658, p. 127). As políticas da mortalidade, isto é, os conflitos comportados pelo cotidiano da atividade polêmica, subsumiam-se a uma política da 
imortalidade, compenetrada da tarefa de resfriar os conflitos no armazém dos livros até que convergissem para uma ordem supostamente pacífica, eterna. ${ }^{56}$

\section{Cartografia do tempo}

"Um espírito naturalmente levado às grandes coisas"; Richelieu é descrito na Relation contenant l'histoire de l'Académie Française como o indivíduo singular cujo dessein previu que o grêmio de letrados pensado para ser eterno devesse partir de uma superação prévia das diferenças entre "partidos" (PELLISSON, 1672, p. 10-14). Em contrapartida ao trabalho hierárquico de exclusão necessariamente implicado na tarefa, Richelieu prometera aos letrados envolvidos com a fundação da Académie liberdade de escolha de seus membros. ${ }^{57}$ Estes haveriam de construí-la para perdurar, o que Paul Pellisson dramatiza aludindo às descrições poéticas de uma república nascente, em que "uns ocupam-se de fazer leis e criar Magistrados, outros de dividir as terras e traçar as plantas das casas; estes de reunir materiais, aqueles de lançar as fundações dos templos ou das muralhas" 58 (PELLISSON, 1672, p. 15). Fundações unidas, de resto, à fortuna teológico-política da monarquia, inscrita nos marcos de sua fundação, que dependeu tanto do cardeal quanto do consentimento de todos os "partidos" do Parlamento (PELLISSON, 1672, p. 66-67). Neles se afirma que a Académie deveria ser espelho de "seu Fundador e de sua autoridade, que, tendo dado forma por si própria a essa instituição,

\footnotetext{
56 “La division se mit entre les Chefs, méme entre les Conseillers qui se querélérent par fois en plein Conseil. Ces diferens étoient immortels; car lors qu'ils se disoient des injures, ils les adressoient à la Postérité leur Confidente; et ils ne s'en pouvoient si bien dédire que la marque et l'Impression n'y parût toûjours".

${ }^{57}$ O gesto constrói a humilitas de Richelieu, que se afasta dos trabalhos de instituição da Academia por força de sua modéstia. Ainda assim, a narrativa de fundação não descuida de postular sua autoridade soberana: "Embora sua modéstia o impedisse de pôr a lume suas grandes obras, no entanto não o impedia de aprovar que se buscasse os mesmos tesouros que ele mantinha ocultos, e de autorizar que fossem buscados" (PELLISSON, 1672, p. 21). "Mais que sa modestie l'empéchant de mettre au jour ses grands ouvrages, ne l'empéchoit pas neantmoins d'approuver qu'on recherchast les mesmes tresors qu'il tenoit cachez, $\&$ d'en autoriser la recherche".

58 "Si vous vous souvenez d'avoir lû dans quelque Poëte la description d'une Republique naissante, où les uns sont occupez à faire des loix $\mathcal{E}$ à créer des Magistrats; les autres à partager les terres $\mathcal{E}$ à tracer le plan des maisons; ceux-cy a assembler des materiaux; ceux-là à jetter les fondemens des temples ou des murailles [...]".
} 
a podia elevar em fundamentos suficientemente fortes para que dure tanto quanto a Monarquia"59 (PELLISSON, 1672, p. 28).

Esses princípios estiveram calcados no procedimento de redução ${ }^{60}$ presente no unico eloquente de Guez de Balzac, na apologia a Henri de Bourbon e na conformidade a que chegam os envolvidos na guerra poética de Furetière. Todos se voltavam para a dissolução das "inconstâncias", motivo recorrente, segundo Pellisson, nas penas de letrados de monarquias rivais. Parte importante do caráter errático da escrita entre letrados franceses de seu tempo residiria no fato de que mesmo os "Autores mais elegantes e polidos tornam-se bárbaros em poucos anos; ressentimo-nos da leitura dos mais sólidos e dos melhores a partir do momento que começam a envelhecer" ${ }^{\prime \prime 61}$ (PELLISSON, 1672, p. 165). Assim, a proteção da Académie - ou, na Nouvelle Allégorique, a organização da paz entre as partes em guerra - articula-se aos objetivos poético-políticos de estabilidade diretamente implicados em valores das cortes de Luís XIII e Luís XIV.

A univocidade aspirada por esse projeto encontra eco na posição "Aristóteles" na Nouvelle Allégorique, dada sua condição singular entre as auctoritates antigas. Ela surge no relato de Furetière quando este descreve que as perdas de Galimatias nas primeiras escaramuças haviam sido compensadas pela fuga da maior parte das tropas para "lugares-comuns, Colégios, entre outras cavernas e asilos". Elas abandonam esses refúgios apenas ao perceber a chegada de novas tropas de Argumentos, as mais temidas entre os seguidores do príncipe insurgente. Compostas por Primeiros Analíticos, Segundos Analíticos e Tópicos, que traziam consigo induções, entimemas, sofismas e silogismos, serviam ao general Aristóteles (FURETIÈRE, 1658, p. 117-120).

Um apoio tão decisivo impõe a Furetière interromper a narrativa, explicando que ele não passava de aparência, "pois aqueles que conheciam o âmago de sua alma sabiam bem que não havia qualquer amizade nem inteligência entre eles"62 (FURETIÈRE, 1658, p. 117-120). O infortúnio de sua aliança com

\footnotetext{
59 "[...] son Fondateur, \& à son autorité, qui seule ayant donné la forme à cette institution, la pouvoit élever sur des fondemens assez forts pour durer autant que la Monarchie".

${ }^{60}$ Lembre-se, ainda, que os estatutos da Académie previam ser suas tarefas decisivas elaborar um Dicionário, uma Gramática, uma Retórica e uma Poética, glórias definitivas a serviço do public (PELLISSON, 1672, p. 160-161).

${ }_{61}$ "Toutes les autres nations reprochent cette inconstance à la nostre; nos Autheurs les plus elegans $\&$ les plus polis deviennent barbares en peu d'années; on se dégouste de la lecture des plus solides, $\mathscr{E}$ des meilleurs, dés qu'ils commencent à vieillir [...]".

62 "[...] en effet, ce n'étoit qu'en apparence qu'il sembloit le favoriser, et sympathiser d'humeur avec luy:car ceux qui le connoissoient dans l'ame, sçavoient bien qu'il n'y avoit nulle amitiéni intelligence entr'eux".
} 
Galimatias derivava de sua posição junto à rainha Filosofia, em ostracismo por ter sido associada à província de Gymnasie. Aristóteles acabou capturado pelas obscuridades dos saberes "Universais" e das "Categorias", bestas-feras responsáveis por engendrar quimeras e abstrações. Retiraram-lhe "tudo que havia de belo e polido nele, disfarçando-o sob vestes hediondas que chamavam Versões, atormentando-o tanto, que o fizeram perder o sentido em diversas ocasiões". Essas sevícias levaram-no, inclusive, a confessar ter "dito e pensado mais coisas de que era inocente" ${ }^{\prime 63}$, abraçando o partido de Galimatias, cujas tropas "comandava com Autoridade" (FURETIÈRE, 1658, p. 124-126).

$\mathrm{O}$ avanço de Aristóteles, somado à desordem do exército de Retórica devido à perda das pensões que sustentavam as figuras, o que as obrigou a procurar outros meios de vida, organiza o fim da história, calcado, de um lado, em um comentário sobre a precariedade das políticas da mortalidade, e, de outro, no louvor à política da imortalidade. Próximos de invadir o último refúgio do reino, as tropas de Galimatias destroem facilmente uma das últimas linhas de defesa, composta por Prefácios e Cartas Dedicatórias, beneficiando da fragilidade do terreno que ocupavam, pois, “[...] foram construídas sobre uma terra chamada Fortuna, que é uma areia movediça sobre a qual ninguém pode fincar bases sólidas [...]; os Prefácios ou Coroamentos não duraram muito mais, pois, como recobrissem um grande terreno, no mais das vezes vago e inútil, havia muitos lugares frágeis e mal construídos, que não podiam ser defendidos [...] ${ }^{64 "}$ (FURETIÈRE, 1658, p. 151-152).

Porque a autoridade máxima de Aristóteles servia de verdadeiro fiel da balança, Retórica e Bom Senso tentam persuadi-lo com o apoio de Intriga, emissária da princesa Poesia, que trama os eventos responsáveis por convencer Aristóteles de que ele era a verdadeira fonte do poder de Galimatias, e não o contrário. Este Aristóteles convertido, reconduzido ao bom partido, lança mão das alianças entre os chefes que lhe eram mais próximos para incitar disputas no campo de Galimatias, oportunidade aproveitada por Intriga para propor um acordo de paz. Uma "paz geral" é prontamente aceita

\footnotetext{
63 "[...] car luy ayant oté tout ce qu'il avoit de beau et de poli, ils le déguisérent sous de méchants habits qu'ils appelloient Versions, et ils le tourmentérent tant, qu'ils luy firent perdre le sens en plusieurs rencontres. Ils le mirent encore à une géne si violente qu'ils luy firent confesser d'avoir dit et pensé plusieurs choses dont il étoit innocent".

${ }^{64}$ "[...] étoient bâties sur une terre appellée Fortune, qui est un sable mouvant, surquoy on ne peut faire aucun fondement solide [...]. Les Préfaces ou Couronnemens ne durérent guere plus; car, comme ils enfermoient un grand terrain, le plus souvent vague et inutile, il y avoit plusieurs endroits faibles et mal terrassez, qui ne se pouvoient défendre [...]".
} 
pelas partes com a celebração de um Tratado contendo catorze cláusulas públicas (e algumas secretas) que asseguravam, entre outros itens, "liberdade de consciência" nos usos "pedantes" e "belos" da linguagem, assim como a inviolabilidade dos territórios dos colégios. Quanto a Aristóteles, o verdadeiro permanece ao lado de Retórica, mas suas "más cópias" têm permissão para seguir com Galimatias. A despeito de escaramuças e comércios escusos travados de tempos em tempos, a "doçura", a "paz" e a "tranquilidade" (FURETIÈRE, 1658, p. 170) são, enfim, preservadas, com a ampla ascendência de Retórica nos negócios do mundo. ${ }^{65}$

Reeditada ainda em 1658, a Nouvelle Allégorique tornou-se modelo autorizado para uma profusão de textos, do Parnasse réformé e La guerre des auteurs anciens et modernes de Gabriel Guéret (1668-71) e da Histoire poétique de la guerre nouvellement déclarée entre les Anciens et les Modernes, de François de Callières (1688), aos Parallèles des Anciens et des Modernes (1688-1697) de Perrault. Mas é Charles Sorel quem demonstra melhor a autoridade da forma de controvérsia desempenhada pela Nouvelle Allégorique, retomando diretamente a estratégia de Jean Goulu para polemizar com Guez de Balzac.

Na sequência das cartas satíricas de Goulu, que criticam a sátira presente nas cartas do unico eloquente, em 1659 Sorel publica a Relation véritable de ce qui s'est passé au royaume de Sophie, depuis les troubles excités par la Rhétorique et l'Éloquence, avec un discours sur la Nouvelle Allégorique. Alegando o motivo da "história verdadeira", assim como Goulu, com sua "verdadeira conformidade", desfere ataques contra a divisão do mundo letrado esboçada por Furetière, propondo uma uniformidade sob o jugo de Sophia, "rainha" que compõe melhor a imagem integrada de conhecimento e escrita galante, doutrina e verbo (BOMBART \& SCHAPIRA, 2004, p. XXIX-XXXI). Novamente se parte da fratura cômica dos partidos rumo ao alinhamento das posições em controvérsia, reunindo sua diversidade sob um conjunto de práticas homogêneas. Com ela, afirma-se a persistência tipológica de um modelo bem-sucedido.

Da anamorfose dos casos analisados, emerge um paradigma de autorização dos discursos. Sob a aparência de conflitos empírico-burlescos, a tentativa de produzir uniformidade das conveniências letradas e políticas; sob

\footnotetext{
${ }^{65}$ Portanto, embora as vulgaridades escolares de Galimatias tenham sido permitidas, conta-se, na lógica do relato, com sua erradicação ao longo do tempo pelo processo de preservação imortal do que é excelente, aspecto decisivo do funcionamento da auctoritas. A univocidade é, ainda, parte do destino irreversivelmente atrelado às Letras francesas, metafisicamente partícipes do destino do corpo político do Estado como um todo.
} 
o caos das guerras, justas letradas doces e polidas; sob a fachada dos acordos de paz, embates pela hierarquização social, pelos dispositivos discursivos, pelas formas de uso dos antigos, pelos modos de querelar. Acima de tudo, uma meditação permanente com o objetivo de resistir aos efeitos corrosivos do tempo, cuja resposta era pintar, a partir de retratos da diversidade letrada, a imagem da estabilidade monárquica. Construir fortalezas contra o tempo, forjar alianças calcadas na dependência, ancorar o reto agir mundano no horizonte das auctoritates: eis precisamente as marcas visíveis nas figuras dispostas ao redor do retrato do cardeal Mazarin realizado por Robert Nanteuil em 1659 (figura 4). Como o quadro esboçado na Nouvelle Allégorique, ele congrega, na ostentação corriqueira do poder, a monumentalidade de gestos, agora exauridos, em busca de uma imortalidade perdida.

\section{Figura 4}

\section{Robert Nanteuil. Cardinal Jules Mazarin Seated Within the Gallery of his Palace}

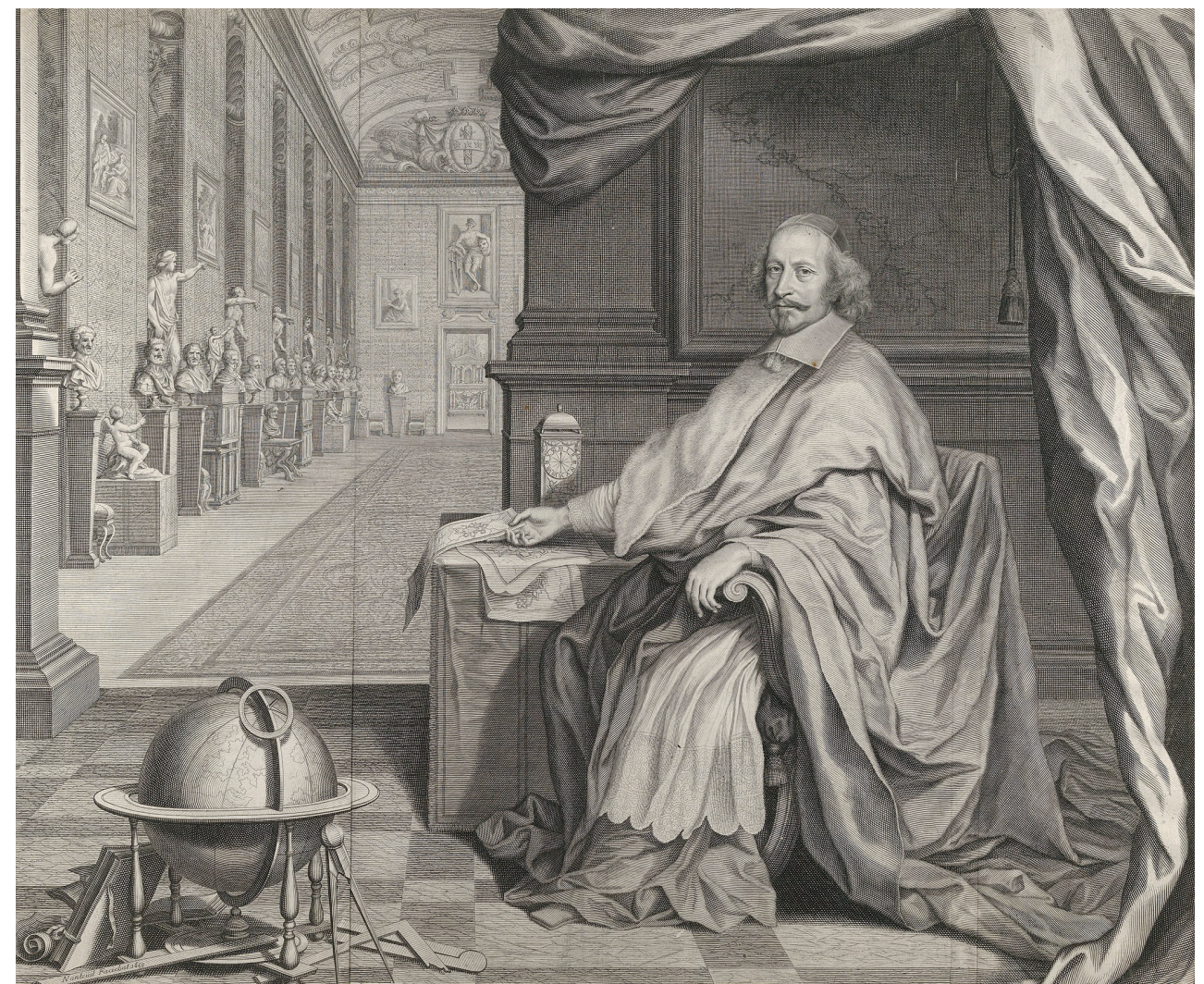

Gravura, 1659. New York: The Metropolitan Museum of Art. Foto: Wikimedia Commons. 


\section{Referências bibliográficas Obras antigas}

ARREST DE LA COUR de Parlement, contre le tres-meschant parricide François Ravaillac. Lyon: Barthelemy Ancelin, 1610.

CHARRON, Pierre. De la Sagesse, livres trois. Bourdeaus: Simon Millanges, 1601.

FURETIÈRE, Antoine. Nouvelle allégorique ou histoire des derniers troubles arrivez au royaume d'eloquence. Paris: Pierre Lamy, 1658.

FURETIÈRE, Antoine. Dictionnaire Universel... le tout extrait des plus excellens anciens $\mathcal{E}$ modernes. Tome Premier. Paris: 1690.

GOULU, Jean. Premiere des Letres de Phyllarque a Ariste, où il est traité de l'Eloquence Française. Paris: Nicolas Buon, 1627.

GOUJET, Claude-Pierre. Bibliothèque française ou Histoire de la littérature française [...]. Paris: P-J Mariette et H-L Guérin, 1741.

NICÉRON, Jean-François. La perspective curieuse, ou Magie artificielle des effets merveilleux de l'optique, par la vision directe, la catoptrique, par la réflexion des miroirs plats, cylindriques et coniques, la dioptrique, par la réfraction des crystaux... Paris: Pierre Billaiine, 1638.

PELLISSON, Paul. Relation contenant l'histoire de l'Académie françoise: augmentée de divers ouvrages du mesme auteur. Paris: Thomas Jolly, 1674.

QUINTILIANO, Marco Fábio. Instituição oratória. Trad. Bruno Fregni Bassetto. Campinas: UNICAMP, 2015.

\section{Literatura secundária}

BOMBART, Mathilde; SHAPIRA, Nicolas. Introduction. In: FURETIÈRE, Antoine. Nouvelle Allégorique ou Histoire des derniers troubles arrivés au Royaume d'Éloquence. Toulouse: Société de Littératures Classiques, 2004.

BOMBART, Mathilde. Un regard sur le monde littéraire: les "Gens de Lettres" et leur querelles. In: SOREL, Charles. La Bibliothèque française (1667). Paris: Honoré Champion, 2015.

CANTILLON, Alain ET AL (orgs.). Introduction. In: Écriture et action: une enquête collective. Paris: Éditions EHESS, 2016.

CHARTIER, Roger; MARTIN, Henri-Jean. Histoire de l'édition française: le livre conquérant. Paris: Fayard, 1989.

CHARTIER, Roger. La main de l'auteur et l'esprit de l'imprimeur. Paris: Gallimard, 2015.

CHARTIER, Roger. Literatura e cultura escrita: permanência das obras, mobilidade dos textos, pluralidade das leituras. In: CHARTIER, Roger; RODRIGUES, José D.; MAGALHÃES, Justino (orgs.). Escritas e cultura na Europa e no Atlântico Modernos. Lisboa: Centro de História da Universidade de Lisboa, 2020.

D'ALLONES, Myriam Revault. Le pouvoir des commencements: essai sur l'autorité. Paris: Seuil, 2006.

DE SÁ, Luiz César. Auctoritas e controvérsia nas práticas letradas francesas (1540-1630). Tese (Doutorado em História Social) - Programa de Pós-Graduação em História Social, Universidade Federal do Rio de Janeiro, Rio de Janeiro, 2017. 
DE SÁ, Luiz César. A autoridade entre os antigos. In: História Unisinos, v. 23, n. 2, p. 215-230, maio/agosto 2019. ISSN 2236-1782. Disponível em: < http://revistas. unisinos.br/index.php/historia/article/view/hist.2019.232.07/60747026>. Acesso em: 02 jan. 2020. doi: http://dx.doi.org/ 10.4013/hist.2019.232.07

HANSEN, João Adolfo. Retórica da agudeza. In: Letras Clássicas, n. 4, 2000.

HANSEN, João Adolfo. A sátira e o engenho: Gregório de Matos e a Bahia do século XVII. São Paulo: Ateliê editorial/UNICAMP, 2004.

HANSEN, João Adolfo. Alegoria: construção e interpretação da metáfora. São Paulo:Hedra, 2006.

HARTOG, François. L'autorité du temps. In : S.E.R, Études. Tome 411, 2009/7.

HOSTIOU, Jeanne-Marie; TADIÉ, Alexis. Querelles et création en Europe à l'époque moderne. Paris: Classiques Garnier, 2019.

JOUHAUD, Christian. Lespouvoirs de la littérature: histoired'un paradoxe. Paris: Gallimard, 2000.

JOUHAUD, Christian. Richelieu et l'écriture du pouvoir: autour de la journée des Dupes. Paris: Gallimard, 2015.

MAL-MAEDER, Danielle. La fiction des déclamations. Leiden: Brill, 2007.

MERLIN-KAJMAN, Hélène. Decorum et bienséance au XVIIe siècle. In: Camenae, $\mathrm{n}^{\mathrm{o}}$ 13, 2012.

MERLIN, Hélène. Guez de Balzac, 'narcisse' épistolier: problèmes d'analyse. In: CHAMAYOU, Anne (org.). Les Lettres ou la règle du Je. Artois: Presses Université, 1999.

MÍSSIO, Edmir. A civilidade e as artes de fingir. São Paulo: EdUSP, 2012.

MONTEFUSCO, Lucia Calboli. Exordium narratio epilogus: studi sulla teoria retorica greca e romana delle parti del discorso. Bologna: CLUEB, 1988.

PÉCORA, Alcir. Máquina de gêneros: novamente descoberta e aplicada a Castiglione, Della Casa, Nóbrega, Camões, Vieira, La Rochefoucauld, Gonzaga, Silva Alvarenga e Bocage. São Paulo: EdUSP, 2001.

PONNOU, Claude et al. Champs de Bataille du Grand Siècle: catalogue des cartes de l'Atlas historique jusqu'à la fin du règne de Louis XIV. Paris: Archives cult, 2013.

ROSSELLINI, Michèle; VIALA, Alain. Charles Sorel bibliografe: du "censeur de livres" au guide des intellectuels. In: SOREL, Charles. La Bibliothèque française (1667). Paris: Honoré Champion, 2015.

SANS, BENOÎT. Exercer l'invention ou (ré)inventer la controverse. In : Rhétorique et citoyenneté, $\mathrm{n}^{\mathrm{O}} 05,2015$.

VAN DAMME, Stéphane. L'épreuve libertine: morale, soupçon et pouvoir dans la France baroque. Paris: CNRS éditions, 2008.

Recebido: 24/02/2021 - Aprovado: 23/09/21

Editores Responsáveis

Miriam Dolhnikoff e Miguel Palmeira 